WSRC-MS--91-154

DE92 015257

\title{
ANALYSIS OF MERCURY DIFFUSION PUMPS
}

by

K. A. Dunn $\mathcal{Q}$ Afur

Westinghouse Savannah River Company

Savannah River Site

Aiken, SC 29808

A paper proposed for presentation at

24th Annual IMS Convention

Monterey, California

July 29 - August 1, 1991

and for publication in the conference proceedings

This paper was prepared in connection with work done under Contract No. DEAC09-89SR 18035 with the U.S. Department of Energy. By acceptance of this paper, the publisher and/or recipient acknowledges the U.S. Government's right to retain a nonexclusive, royalty-free license in and to any copyright covering this paper, along with the right to reproduce and to authorize others to reproduce all or part of the copyrighted paper. 


\title{
ANALYSIS OF MERCURY DIFFUSION PUMPS
}

\author{
Kerry A. Dunn'1
}

\begin{abstract}
Several mercury diffusion pump stages in the Tritium Purification process at the Savannah River Site (SRS) have been removed from service for scheduled preventive maintenance. These stages have been examined to determine if failure has occurred. Evidence of fatigue around the flange portion of the purap has been seen. In addition, erosion and cavitation inside the throat of the venturi tube and corrosion on the other surface of the venturi tube has been observed. Several measures are being examined in an attempt to improve the performance of these purnps. These measures, as well as the noted observations, are described.
\end{abstract}

Westinghouse Savannah River Company, Sevannah River Laboratory, Aiken, SC 29802

\section{DISCLAIMER}

This report was prepared as an account of work sponsored by an agency of the United States Government. Neither the United States Government nor any agency thereof, nor any of their employees, makes any warranty, express or implied, or assumes any legal liability or responsibility for the accuracy, completeness, or usefulness of any information, apparatus, product, or process disclosed, or represents that its use would not infringe privately owned rights. Reference herein to any specific commercial product, process, or service by trade name, trademark, manufacturer, or otherwise does not necessarily constitute or imply its endorsement, recommendation, or favoring by the United States Government or any agency thereof. The views and opinions of authors expressed herein do not necessarily state or reflect those of the United States Government or any agency thereof. 


\section{SUMMARY}

Six stages [two machined (MP) and four electron beam (EB) welded] from the mercury diffusion pumps operating in the Tritium Purification process at SRS have been analyzed to determine their condition after nine months of usage. Several cracks were found around the necked region of the two MP stages. The EB welded stages, however, seemed to perform better in service-two of four stages showed cracking. The cracking is caused by facigue that has been enhanced by high stresses and tritium in the flange area.

The EB welded stage appears to be a step in the right direction. Since the EB weld is a shrink fit, the surface is in compression, thereby eliminating crack propagation. In addition, shot peening has been employed to produce a compressive material surface since fatigue usually originates at the surface.

Pitting was observed down the throat of the venturi. This pitting was caused by cavitation and erosion along the lengin of the venturi tube.

Corrosion and pitting was seen on the exterior walls of the diffuser tubes. Stress-corrosion cracts were observed emanating from these corrosion pits. The corrosion likely occurred from the chioride ions present in the process cooling water. Shot peening is now being used in an attempt to place the outside of the diffuser tube in compression to eliminate the stress-corrosion cracking.

\section{INTRODUCTION}

The mercury diffusion pump in tritium is a three-stage, booster-ejector pump originally manufactured by Consolidated Vacuum Corporation (CVC). This pump pulls gas from the furnaces through a uranium decomposer bed to the Sprengel forepumps for further purification. The unit can increase gas pressure from microns up to approximately $30 \mathrm{kPa}$, with a maximum capacity of approximately $8000 \mathrm{~cm}^{3} /$ minute (similar to most $\mathrm{Hg}$ vecuum pumps). Mercury is vaporized in the boiler and pushed to the top of the pump where it condenses and entrains incoming gas and flows downward through a diffuser tube or venturi. The diffuser tubes are cooled by the surrounding cooling water jackets that initially condense the mercury as it flows down the venturi [1]. The mercury vapor temperature ins: te the diffuser tube is around 573K and the jutside temperature is about $293 \mathrm{~K}$, which creates a tremendous thermal gradient between the walls. Figure 1 represents one stage of the mercury diffusion booster-ejector pump.

There are two mercury diffusion pumps (237 and 232) in the Tritium Purification process at SRS. The 237 pump require a more rigorous cperation than the 232 pump because it sees tritium gas prior to purification. Once the gas reaches the 232 pump, it has alreauty been through the uranium decomposer bed and the palladium/silver siffuser for purification. Originally, the position of the stages and their performance were thought to be independent of one another. However, because of insufficient evidence for that hypothesis, stage performance in reference to position is now being monitored. 
The original mercury diffusion pump stage design incorporated a tungsten inert gas (TIG) weld to interface the flange with the diffuser tube. Failures with these stages, at the TIG weld, occurred in 1986 and 1987 after only three months of service. An investigation was initiated to determine how the life of the diffuser stages could be extended.

Finite element analyses were employed to coamine the stress states that were present due to thermal stress, residual weld stress, shrink-fit weld stress, and the combination of thermal and residual weld or shrint-fit weld stresses on the stage of the mercury diffusion pump diffusers [2]. The analyses showed that the presence of principal stresses, as a result of high bending stresses, were located in the venturi tube area and the necked region for the thermal case. However, the stress analysis for the residual welding stress case predicted tensile stresses in the horizontal and necked regions of the mercury diffusion pump stage. According to the study, neither of the strese-related problems would, separately, cause any cracking through the wall. However, combining the two stresses would result in high-tensile stresses located in the necked region. From this finite element analysis, several modifications to the previous design were made. The two most recent designs included a stage machined out of a single block of steel, while the other design incorporated a shrink-fit EB weld between the top flange and the diffuser tube.

In an attempt to maintain failure-free pumpe, the current preventive maintenance schedule requires the removal of the third stages after nine months of service and the first and second stages after 18 months of service. Although no service failures have occurred while using this preventive maintenance regimen, cracking has been observed. Table 1 shows the third stages ecamined and their properties.

\section{PROCEDURE}

All stages removed from service were tested with a dye penetrant to deternine if any cracking was visible in the necked region of the stages. Once tested, cracked stages were stored in an air hood until the material had sufficiently outgassed. This was done so that sectioning could be performed without tritium contamination. Most of the flange was cut away to expose the diffuser tube region. The diffuser tubes were sectioned along their length adjacent to cracks. Once the pieces were of the workable size, stereomicroscopy and scanning electron microscopy (SEM) were used to examine the cracks in the necked region of the venturi. In addition, metallography was used to examine both crack morphology and crack depth.

Energy dispersive spectroscopy (EDS) was used to examine the extraneous debris on the inner surface of the diffuser tube as well as the corrosion product on the water side. SEM was employed to examine pitting of both the inner and outer surfaces of the stage prior to metallographic examination of the pits and cracking. 


\section{RESULTS AND DISCUSSION}

Dye-penetrant checks of the first and second stages showed no cracking in the flange. Since these stages see a smaller velocity of gas and mercury flowing through them, their cyclic and tensile stresses are lower, therefore decreasing the probability of fatigue failure.

One of the more recent designs has inwolved machining the stages out of a single block of $304 \mathrm{~L}$ stainless steel in an attempt to eliminate flaws that may be introduced by welding processes. Two machined third stages were removed from service, one in 1988 and one in 1990. Dye-penetrant testing revealed approximately 12 cracks around the necked portion of each stage (Figures 2 and 3). A full destructive examination of both the $1988 \mathrm{MP}$ and the $1990 \mathrm{MP}$ stages has been conducted.

Another design that has been examined recently is the shrink-fit, EB weld tech-ique to connect the diffuser tube to the top flange. The shrint fit was used to place the origin of cracking (inside surface of necked region) in compression. In two of the four EB welded third stages removed from service since 1988, dye-penetrant testing revealed cracking (Figures 4 and 5 ).

Previous investigations by Ehrhart and Eberhand $[1,3]$ have attributed the mercury diffusion pump failures to liquid metal embrittlement and stress-induced Cicixing. They also claim that mercury globules were present in the cracks of the metallographic specimen. It is not unusual, however, that mercury droplets were found in the cracks since mercury flows through the tubing. Furthermore, any type of debris present on the parts will tend to congregate at a crack site. Upon examination of liquid metal embrittled samples, one should see a complete coating of the liquid metal. In fact, the liquid metal is in such close contact with the solid that it is generally difficult to remove. Therefore, the presence of mercury droplets in the crack is not sufficient justification for concluding liquid metal embrittlement. The present studies found no coating of mercury, but a few mercury droplets were observed. Liquid metal embrittlement has, for the most part, been ruled out as the failure mechanism.

Following the sectioning of the stages, it was observed that the cracks in all samples were approximately $2-4 \mathrm{~cm}$ along the length of the diffuser tube. The cracks were examined by SEM (Figure 6). It was unclear from these micrographs whether the cracking occurred intergranularly or transgranularly. In addition, the SEM of opened cracks did not reveal a crack origin or reason for fracture. Several particles were observed on the interior surface of the stages near to and around the cracks (Figure 7). The particles were rich in silicon ( $\mathrm{Si}$ ), aluminum (Al), and potassium (K), as shown by the EDS spectrum in Figure 8. Although great in number, the particles were probably not a factor in the failure of the mercury diffusion pumps. There are two possible explanations for the presence of the particles. First, $\mathrm{A}$ and $\mathrm{Si}$ were observed during an elemental examination of a 
spot-check penetrant used in the dye-penetrant testing (Figure 9). The second explanation deals with the presence of zeolite beds upstream in the process, which may provide a source of $\mathrm{Al}, \mathrm{Si}$, and $\mathrm{K}$.

Cross-sections of the top portion of four mercury diffusion pump stages were cut to conduct metallographic exminations. Optical microecopy on the mercury diffusion pump stage pieces was employed to obeerve the cracting in the necked regions (Figures 10-12). As can be clearty seen, the cracks are mostly transgranular in nature. Propagntion of the crack has occurred from the inside of the necked region toward the outside wall and is not indicative of strese-corrosion cracking. In addition, no pitting is visible at the origin of the cracking. The cracks appear to be mainly related to fatigue. They are clean, there is not much branching, and they are fairly straight. The cracks extended, at the most, one-third of the way into the sections and no through-wall cracks were observed. This is not unusual since the cyclic stress needed to cause fatigue cracking is less than the yield stress of the material. Therefores a through-wall crack may not cocur at all.

There were unusual regions observed in the metallographic section of the 1989 EB welded stage shown in Figure 12. They are small, approwimately $5 \mu \mathrm{m}$ in diameter, and appear to be ferrite. Figure 13, a longitudinal section from this same area, shows the presence of stringers (probably ferrite). Transmission electron microscopy (TEM) was employed to identify these artifacts. Particles found in the matrix were either chromium $(\mathrm{Cr})$ and manganesc $(\mathrm{Mn})$ rich or manganese suifide (MnS) inclusions (Figures 14 and 15). Because of problems with thinning, the particles in Figare 14 could not be identified with diffraction patterns. Since $\mathrm{Cr}$ is a ferrite stabilizer, it is likely that the particles are ferrite. However, because of the lack of diffraction information and the presence of $\mathbf{M n}$. ferrite cannot be confirmed.

A large degree of pitting was observed down the length of the venturi tube, primarily in the 1988 stages that were examined. The $1988 \mathrm{~EB}$ welded piece was pitted far more than the remaining stages. Macrographs representative of the pits that formed on the interior wall of the 1988 EB welded stage are shown in Figure 16, while SEM micrographs of the pitting are shown in Figure 17. The appearance of the pits is typical of cavitation, which involves a material buildup along a surface. The pressure is increased at the surface into a range such that a cavity is formed from the force of the eventual presure release. As indicated by the micrographs, the pits are approximatety $62.5 \mu \mathrm{m}$ deep and numerous.

SEM micrographs representative of the pitting in the 1988 MP piece can be seen in Figure 18. The pits in the MP piece typify erosion pitting, where erosion is defined as the removal of surface material due to numerous impacts of the surface from solid or liquid particles. 
WSRC-MS--91-154

DE92 015257

\section{ANALYSIS OF MERCURY DIFFUSION PUMPS}

by

K. A. Dunn $\mathcal{Q}$ Afur

Westinghouse Savannah River Company

Savannah River Site

Aiken, SC 29808

A paper proposed for presentation at

24th Annual IMS Convention

Monterey, California

July 29 - August 1, 1991

and for publication in the conference proceedings

This paper was prepared in connection with work done under Contract No. DEAC09-89SR 18035 with the U.S. Department of Energy. By acceptance of this paper, the publisher and/or recipient acknowledges the U.S. Government's right to retain a nonexclusive, royalty-free license in and to any copyright covering this paper, along with the right to reproduce and to authorize others to reproduce all or part of the copyrighted paper. 


\title{
ANALYSIS OF MERCURY DIFFUSION PUMPS
}

\author{
Kerry A. Dunn'1
}

\begin{abstract}
Several mercury diffusion pump stages in the Tritium Purification process at the Savannah River Site (SRS) have been removed from service for scheduled preventive maintenance. These stages have been examined to determine if failure has occurred. Evidence of fatigue around the flange portion of the purap has been seen. In addition, erosion and cavitation inside the throat of the venturi tube and corrosion on the other surface of the venturi tube has been observed. Several measures are being examined in an attempt to improve the performance of these purnps. These measures, as well as the noted observations, are described.
\end{abstract}

Westinghouse Savannah River Company, Sevannah River Laboratory, Aiken, SC 29802

\section{DISCLAIMER}

This report was prepared as an account of work sponsored by an agency of the United States Government. Neither the United States Government nor any agency thereof, nor any of their employees, makes any warranty, express or implied, or assumes any legal liability or responsibility for the accuracy, completeness, or usefulness of any information, apparatus, product, or process disclosed, or represents that its use would not infringe privately owned rights. Reference herein to any specific commercial product, process, or service by trade name, trademark, manufacturer, or otherwise does not necessarily constitute or imply its endorsement, recommendation, or favoring by the United States Government or any agency thereof. The views and opinions of authors expressed herein do not necessarily state or reflect those of the United States Government or any agency thereof. 


\section{SUMMARY}

Six stages [two machined (MP) and four electron beam (EB) welded] from the mercury diffusion pumps operating in the Tritium Purification process at SRS have been analyzed to determine their condition after nine months of usage. Several cracks were found around the necked region of the two MP stages. The EB welded stages, however, seemed to perform better in service-two of four stages showed cracking. The cracking is caused by facigue that has been enhanced by high stresses and tritium in the flange area.

The EB welded stage appears to be a step in the right direction. Since the EB weld is a shrink fit, the surface is in compression, thereby eliminating crack propagation. In addition, shot peening has been employed to produce a compressive material surface since fatigue usually originates at the surface.

Pitting was observed down the throat of the venturi. This pitting was caused by cavitation and erosion along the lengin of the venturi tube.

Corrosion and pitting was seen on the exterior walls of the diffuser tubes. Stress-corrosion cracts were observed emanating from these corrosion pits. The corrosion likely occurred from the chioride ions present in the process cooling water. Shot peening is now being used in an attempt to place the outside of the diffuser tube in compression to eliminate the stress-corrosion cracking.

\section{INTRODUCTION}

The mercury diffusion pump in tritium is a three-stage, booster-ejector pump originally manufactured by Consolidated Vacuum Corporation (CVC). This pump pulls gas from the furnaces through a uranium decomposer bed to the Sprengel forepumps for further purification. The unit can increase gas pressure from microns up to approximately $30 \mathrm{kPa}$, with a maximum capacity of approximately $8000 \mathrm{~cm}^{3} /$ minute (similar to most $\mathrm{Hg}$ vecuum pumps). Mercury is vaporized in the boiler and pushed to the top of the pump where it condenses and entrains incoming gas and flows downward through a diffuser tube or venturi. The diffuser tubes are cooled by the surrounding cooling water jackets that initially condense the mercury as it flows down the venturi [1]. The mercury vapor temperature ins: te the diffuser tube is around 573K and the jutside temperature is about $293 \mathrm{~K}$, which creates a tremendous thermal gradient between the walls. Figure 1 represents one stage of the mercury diffusion booster-ejector pump.

There are two mercury diffusion pumps (237 and 232) in the Tritium Purification process at SRS. The 237 pump require a more rigorous cperation than the 232 pump because it sees tritium gas prior to purification. Once the gas reaches the 232 pump, it has alreauty been through the uranium decomposer bed and the palladium/silver siffuser for purification. Originally, the position of the stages and their performance were thought to be independent of one another. However, because of insufficient evidence for that hypothesis, stage performance in reference to position is now being monitored. 
The original mercury diffusion pump stage design incorporated a tungsten inert gas (TIG) weld to interface the flange with the diffuser tube. Failures with these stages, at the TIG weld, occurred in 1986 and 1987 after only three months of service. An investigation was initiated to determine how the life of the diffuser stages could be extended.

Finite element analyses were employed to coamine the stress states that were present due to thermal stress, residual weld stress, shrink-fit weld stress, and the combination of thermal and residual weld or shrint-fit weld stresses on the stage of the mercury diffusion pump diffusers [2]. The analyses showed that the presence of principal stresses, as a result of high bending stresses, were located in the venturi tube area and the necked region for the thermal case. However, the stress analysis for the residual welding stress case predicted tensile stresses in the horizontal and necked regions of the mercury diffusion pump stage. According to the study, neither of the strese-related problems would, separately, cause any cracking through the wall. However, combining the two stresses would result in high-tensile stresses located in the necked region. From this finite element analysis, several modifications to the previous design were made. The two most recent designs included a stage machined out of a single block of steel, while the other design incorporated a shrink-fit EB weld between the top flange and the diffuser tube.

In an attempt to maintain failure-free pumpe, the current preventive maintenance schedule requires the removal of the third stages after nine months of service and the first and second stages after 18 months of service. Although no service failures have occurred while using this preventive maintenance regimen, cracking has been observed. Table 1 shows the third stages ecamined and their properties.

\section{PROCEDURE}

All stages removed from service were tested with a dye penetrant to deternine if any cracking was visible in the necked region of the stages. Once tested, cracked stages were stored in an air hood until the material had sufficiently outgassed. This was done so that sectioning could be performed without tritium contamination. Most of the flange was cut away to expose the diffuser tube region. The diffuser tubes were sectioned along their length adjacent to cracks. Once the pieces were of the workable size, stereomicroscopy and scanning electron microscopy (SEM) were used to examine the cracks in the necked region of the venturi. In addition, metallography was used to examine both crack morphology and crack depth.

Energy dispersive spectroscopy (EDS) was used to examine the extraneous debris on the inner surface of the diffuser tube as well as the corrosion product on the water side. SEM was employed to examine pitting of both the inner and outer surfaces of the stage prior to metallographic examination of the pits and cracking. 


\section{RESULTS AND DISCUSSION}

Dye-penetrant checks of the first and second stages showed no cracking in the flange. Since these stages see a smaller velocity of gas and mercury flowing through them, their cyclic and tensile stresses are lower, therefore decreasing the probability of fatigue failure.

One of the more recent designs has inwolved machining the stages out of a single block of $304 \mathrm{~L}$ stainless steel in an attempt to eliminate flaws that may be introduced by welding processes. Two machined third stages were removed from service, one in 1988 and one in 1990. Dye-penetrant testing revealed approximately 12 cracks around the necked portion of each stage (Figures 2 and 3). A full destructive examination of both the $1988 \mathrm{MP}$ and the $1990 \mathrm{MP}$ stages has been conducted.

Another design that has been examined recently is the shrink-fit, EB weld tech-ique to connect the diffuser tube to the top flange. The shrint fit was used to place the origin of cracking (inside surface of necked region) in compression. In two of the four EB welded third stages removed from service since 1988, dye-penetrant testing revealed cracking (Figures 4 and 5 ).

Previous investigations by Ehrhart and Eberhand $[1,3]$ have attributed the mercury diffusion pump failures to liquid metal embrittlement and stress-induced Cicixing. They also claim that mercury globules were present in the cracks of the metallographic specimen. It is not unusual, however, that mercury droplets were found in the cracks since mercury flows through the tubing. Furthermore, any type of debris present on the parts will tend to congregate at a crack site. Upon examination of liquid metal embrittled samples, one should see a complete coating of the liquid metal. In fact, the liquid metal is in such close contact with the solid that it is generally difficult to remove. Therefore, the presence of mercury droplets in the crack is not sufficient justification for concluding liquid metal embrittlement. The present studies found no coating of mercury, but a few mercury droplets were observed. Liquid metal embrittlement has, for the most part, been ruled out as the failure mechanism.

Following the sectioning of the stages, it was observed that the cracks in all samples were approximately $2-4 \mathrm{~cm}$ along the length of the diffuser tube. The cracks were examined by SEM (Figure 6). It was unclear from these micrographs whether the cracking occurred intergranularly or transgranularly. In addition, the SEM of opened cracks did not reveal a crack origin or reason for fracture. Several particles were observed on the interior surface of the stages near to and around the cracks (Figure 7). The particles were rich in silicon ( $\mathrm{Si}$ ), aluminum (Al), and potassium (K), as shown by the EDS spectrum in Figure 8. Although great in number, the particles were probably not a factor in the failure of the mercury diffusion pumps. There are two possible explanations for the presence of the particles. First, $\mathrm{A}$ and $\mathrm{Si}$ were observed during an elemental examination of a 
spot-check penetrant used in the dye-penetrant testing (Figure 9). The second explanation deals with the presence of zeolite beds upstream in the process, which may provide a source of $\mathrm{Al}, \mathrm{Si}$, and $\mathrm{K}$.

Cross-sections of the top portion of four mercury diffusion pump stages were cut to conduct metallographic exminations. Optical microecopy on the mercury diffusion pump stage pieces was employed to obeerve the cracting in the necked regions (Figures 10-12). As can be clearty seen, the cracks are mostly transgranular in nature. Propagntion of the crack has occurred from the inside of the necked region toward the outside wall and is not indicative of strese-corrosion cracking. In addition, no pitting is visible at the origin of the cracking. The cracks appear to be mainly related to fatigue. They are clean, there is not much branching, and they are fairly straight. The cracks extended, at the most, one-third of the way into the sections and no through-wall cracks were observed. This is not unusual since the cyclic stress needed to cause fatigue cracking is less than the yield stress of the material. Therefores a through-wall crack may not cocur at all.

There were unusual regions observed in the metallographic section of the 1989 EB welded stage shown in Figure 12. They are small, approwimately $5 \mu \mathrm{m}$ in diameter, and appear to be ferrite. Figure 13, a longitudinal section from this same area, shows the presence of stringers (probably ferrite). Transmission electron microscopy (TEM) was employed to identify these artifacts. Particles found in the matrix were either chromium $(\mathrm{Cr})$ and manganesc $(\mathrm{Mn})$ rich or manganese suifide (MnS) inclusions (Figures 14 and 15). Because of problems with thinning, the particles in Figare 14 could not be identified with diffraction patterns. Since $\mathrm{Cr}$ is a ferrite stabilizer, it is likely that the particles are ferrite. However, because of the lack of diffraction information and the presence of $\mathbf{M n}$. ferrite cannot be confirmed.

A large degree of pitting was observed down the length of the venturi tube, primarily in the 1988 stages that were examined. The $1988 \mathrm{~EB}$ welded piece was pitted far more than the remaining stages. Macrographs representative of the pits that formed on the interior wall of the 1988 EB welded stage are shown in Figure 16, while SEM micrographs of the pitting are shown in Figure 17. The appearance of the pits is typical of cavitation, which involves a material buildup along a surface. The pressure is increased at the surface into a range such that a cavity is formed from the force of the eventual presure release. As indicated by the micrographs, the pits are approximatety $62.5 \mu \mathrm{m}$ deep and numerous.

SEM micrographs representative of the pitting in the 1988 MP piece can be seen in Figure 18. The pits in the MP piece typify erosion pitting, where erosion is defined as the removal of surface material due to numerous impacts of the surface from solid or liquid particles. 
The pits in both the 1988 EB piece and the 1988 MP piece had several particles in them that were rich in $\mathrm{Al}, \mathrm{Si}$, and $\mathrm{K}$. However, the particles are not attributed to the cracking in the pump or the pitting. They are believed to be from the process system.

It is evident from the metallography performed on the cross section of the 1988 EB part that, although the pits were very prominent and visible, none of the interior wall pits propagated cracks (Figure 19). This fact is encouraging since the interior of the mercury diffusion pump atage should be in compression from the shrink-fit weld. The pits on the 1938 MP arge (Figure 20) are not as noticeable by metallography as those from the $1938 \mathrm{~EB}$ welded stage.

The fact that no cracks were found propagating from the cavitation/erosion pits in $1988 \mathrm{MP}$ and $1988 \mathrm{~EB}$ and that pitting was not evident of the interior walls of the two 1989 EB welded stages provides sound reasoning to assume that the pitting will not contribute to the failure of the pump.

There were, however, several corrosion pits obeerved on the exterior wall of most diffuser tubes examined. The pits acted as crack initiators in the $1988 \mathrm{~EB}$ and 1988 MP stages (Figures 19-22). The cracting that was observed typifies stress-corrosion cracting. Chioride ions present in the cooling water are suspected to be the corrodive medium. To combat this problem, the outer walls are now shot peened to place the surface in compression. Stage $1990 \mathrm{~EB}$ was shot peened on the outside of the diffuser tube and it did not exhibit any corrosion.

\section{CONCLUSIONS}

Table 2 shows the results from the stage analyses. From the course of these analyses, several conclusions can be made. The EB shrink-fit weld procedure is necessary since it appears to have eliminated much of the tensile stress associated with the mercury diffusion pumps. A decreased number of cracks present around the necked portion of the diffuser tube indicates that the design and strength of the material is a step in the right direction. However, it is important to note that material quality is a necessity to having failure-free pumps. Machining the stages out of a single piece of metal will be eliminated because of the presence of numerous cracts observed in the examined stages.

Shot peening the entire surface of the flange also seems to have an advantageous effect toward eliminating the cracts in the mercury diffusion pump stages. However, the shot peening must be conducted on the entire flange rather than from the EB weld outward, or not at all. Stage 1990 EB, the only stage that was shot peened on the entire flange, did not have any cracks in the necked region of the diffuser tube. However, of the three stages that were not shot peened on the entire flange, $1988 \mathrm{~EB}, 1989 \mathrm{~EB}$, and $1989 \mathrm{~EB}$ (cracked), two had cracks in the necked region of the diffuser. 
Shot peening produces compressive residual stresses on the surface by the introduction of a high-yelocity stream of shot to the surface. With the material surface in compression, the cracks are inhibited. However, the cracks will propagate once the stress is overcome. Future analyses of thind stages will continue to provide information on the suocess of the shot peening.

No cracts were observed propagating from the erosion/cavitation pits in the 1988 MP stage and the 1988 EB stage. In addition, no significant cavitation or erosion was observed along the inside length of the diffuser tubes from the remaining four stages examined. Therefore, neither the cavitation nor the erosion should be deleterious to the life of the mercury diffusion pump stages.

Finally, shot peening the outside of the diffuser tube has been used to eliminate the strese-corrosion pitting and crack propagation associated with the chloride ions. Since shot peening has been shown to provide protection against corrosion and crack propagation, it will continue to be used on future mercury diffusion pump stages.

\section{REFERENCES}

1) W. S. Ehrhart and B. A. Eberhard, EED850081, "Failed CVC-237 Mercury Pump Stage", 1985.

2) R. J. Thomas and J. M. Cahill, 863807, "Savannah River Plant 232-H Thitium Facilities Booster Pump Diffuser Stress Analysis", 1985.

3) W. S. Ehrhart and B. A. Eberhard, EED850343, "Cracked CVC-232-F Mercury Pump - 3rd Stage Diffuser", 1985,

4) R. J. Thomas and J. M. Cahill, WR864295, "Savannah River Plant - Tritium Facilities - 232-H CVC Pump Repair Assistance Three Stage Diffuser Stress Analysis Interference Fit", 1987.

\section{ACKNOWLEDGMENT}

The information contained in this paper was developed during the course of work done under Contract No. DE-AC09-89 SR18035 with the U.S. Department of Energy. 
Table 1. Mercury Diffusion Pump Stage Information

\begin{tabular}{|c|c|c|c|c|}
\hline Name & Stage & $\begin{array}{l}\text { Start Date } \\
\text { Errmine }\end{array}$ & How Pahricated & $\begin{array}{l}\text { Pump } \\
\text { Position }\end{array}$ \\
\hline $1988 \mathrm{~EB}$ & $3^{\text {nd }}$ & $10 / 88$ & EB welded & - \\
\hline $1988 \mathrm{MP}$ & $3^{\text {nd }}$ & $10 / 88$ & machined from single block & 一 \\
\hline $\begin{array}{l}1989 \mathrm{~EB} \\
\text { (cracked) }\end{array}$ & $3^{\text {nd }}$ & $10 / 89$ & $\begin{array}{l}\text { EB welded and shot } \\
\text { peened from weld to outer flange }\end{array}$ & - \\
\hline 1989 EB & $3^{\text {nd }}$ & $10 / 89$ & $\begin{array}{l}\text { EB welded and shot } \\
\text { peened from weld to outer flange }\end{array}$ & - \\
\hline $1990 \mathrm{~EB}$ & $3^{\text {nd }}$ & $7 / 90$ & $\begin{array}{l}\text { EB welded and shot peened } \\
\text { on all flange and outer venturi }\end{array}$ & 237 \\
\hline $1990 \mathrm{MP}$ & $3^{\text {rnd }}$ & $7 / 90$ & machined from single block & 232 \\
\hline
\end{tabular}

Table 2. Results from Mercury Diffusion Pump Stage Anatyses

\begin{tabular}{|c|c|c|c|c|}
\hline Name. & $\begin{array}{l}\text { Cracks in } \\
\text { Dinnee }\end{array}$ & $\begin{array}{l}\text { Pits Inside } \\
\text { Difinser. }\end{array}$ & $\begin{array}{l}\text { Pits Ontaide } \\
\text { Dimerer }\end{array}$ & Shot Pren \\
\hline $1988 \mathrm{~EB}$ & 1 & yes-cavitation & $\begin{array}{l}\text { yes-corrosion and } \\
\text { crack propagation }\end{array}$ & no \\
\hline $1988 \mathrm{MP}$ & -12 & yes-erosion & $\begin{array}{l}\text { yes-corrosion and } \\
\text { crack propagation }\end{array}$ & no \\
\hline $\begin{array}{l}1989 \text { EB } \\
\text { (cracked) }\end{array}$ & -6 & no & $\begin{array}{l}\text { corrosion product/no } \\
\text { cracking }\end{array}$ & $\begin{array}{l}\text { yes - veld } \\
\text { out on flange }\end{array}$ \\
\hline 1989 EB & no & no & $\begin{array}{l}\text { corrosion product/no } \\
\text { cracking }\end{array}$ & $\begin{array}{l}\text { yes-EB weld } \\
\text { out on flange }\end{array}$ \\
\hline 1990 EB & no & no & $\begin{array}{l}\text { no pits or corrosion } \\
\text { product }\end{array}$ & $\begin{array}{l}\text { yes-all flange } \\
\text { surface and } \\
\text { outside diffuser }\end{array}$ \\
\hline $1990 \mathrm{MP}$ & $=12$ & no & $\begin{array}{l}\text { some corrosion/no } \\
\text { gracking }\end{array}$ & no \\
\hline
\end{tabular}




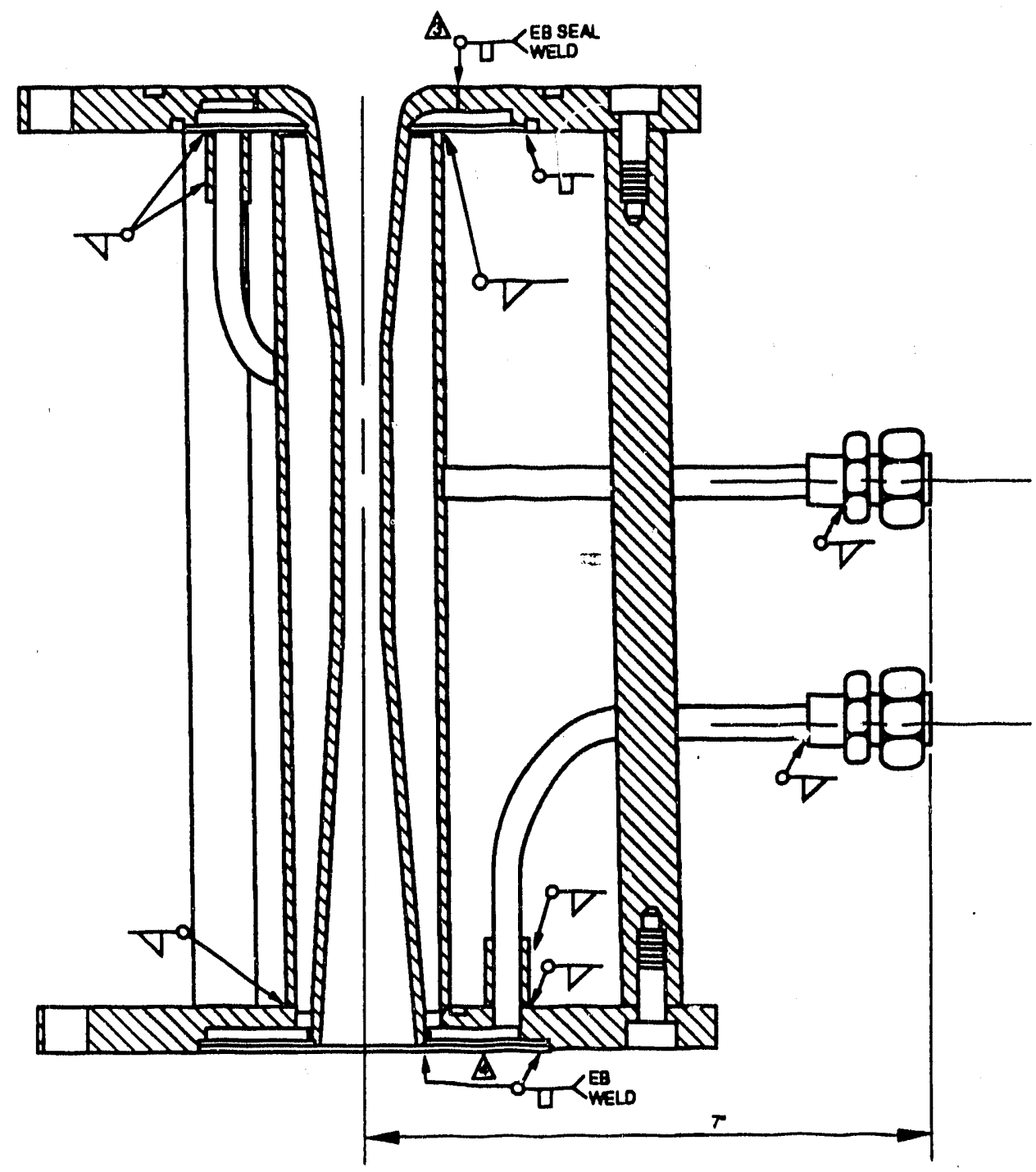

M91aug001.01

Figure 1. Schematic of CVC Third Stage 


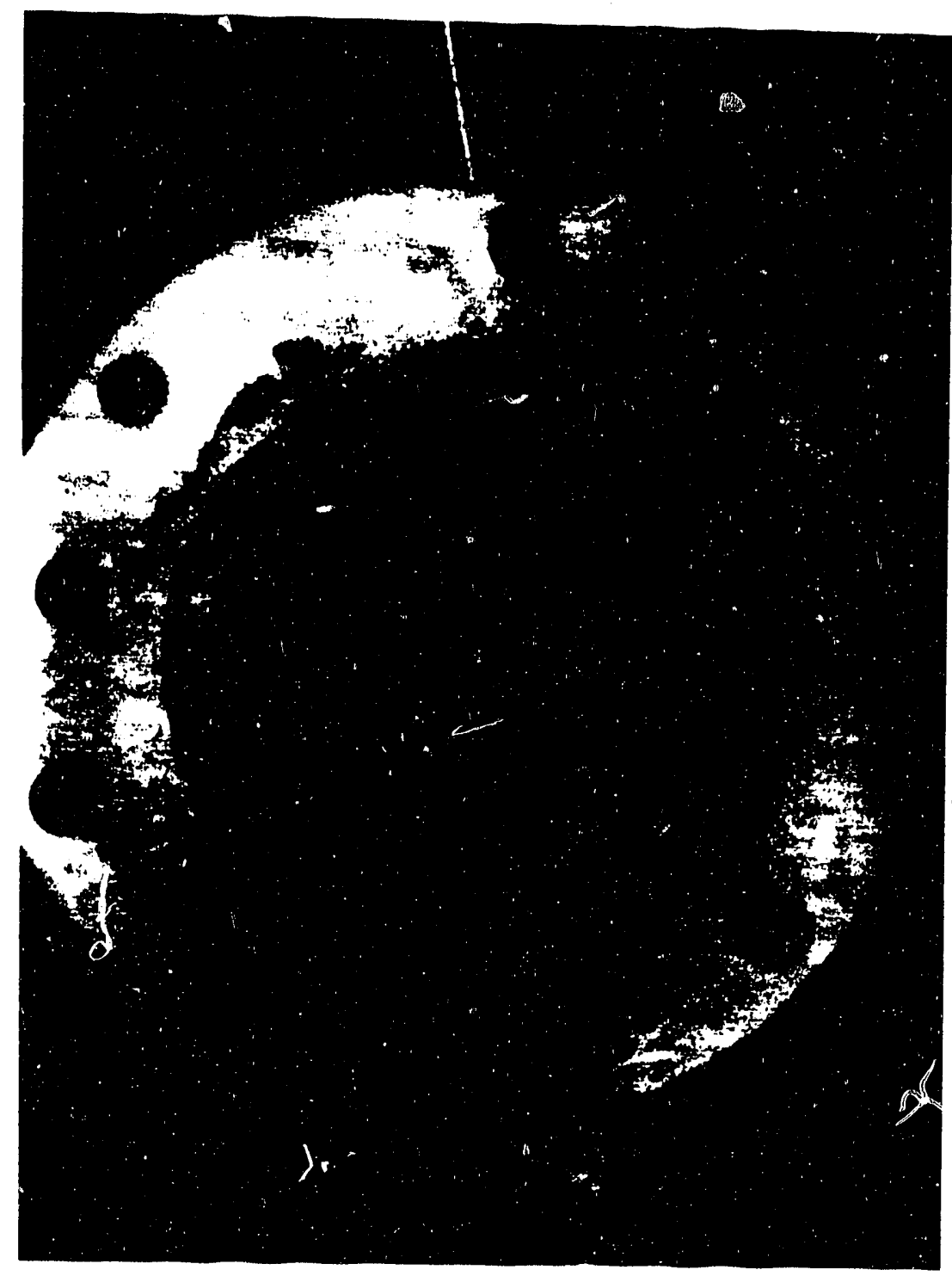

Figure 2. Dye-Penetrant Test from 1988 MP 


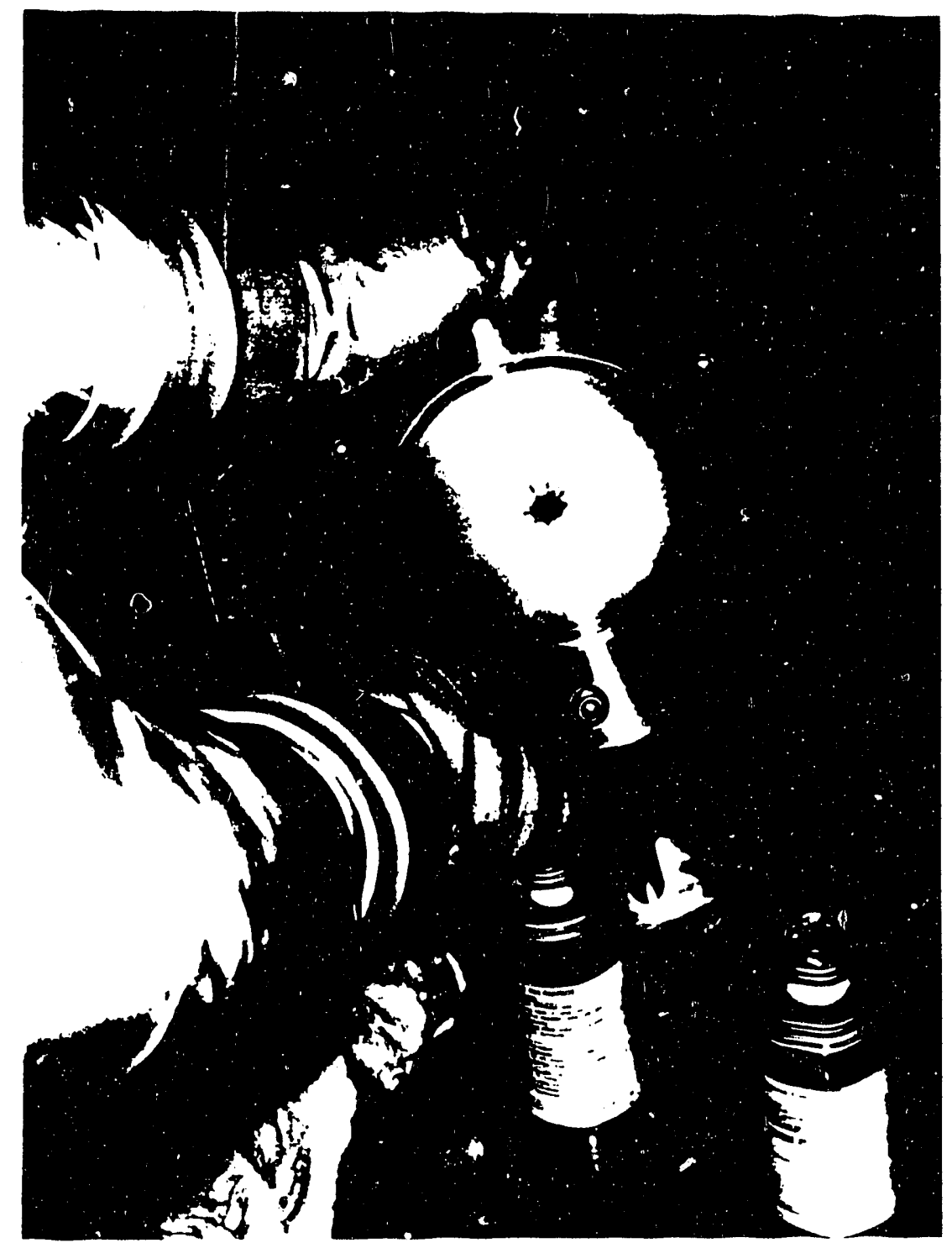

Figure 3. Dye-Penetrant Test from 1990 MP 


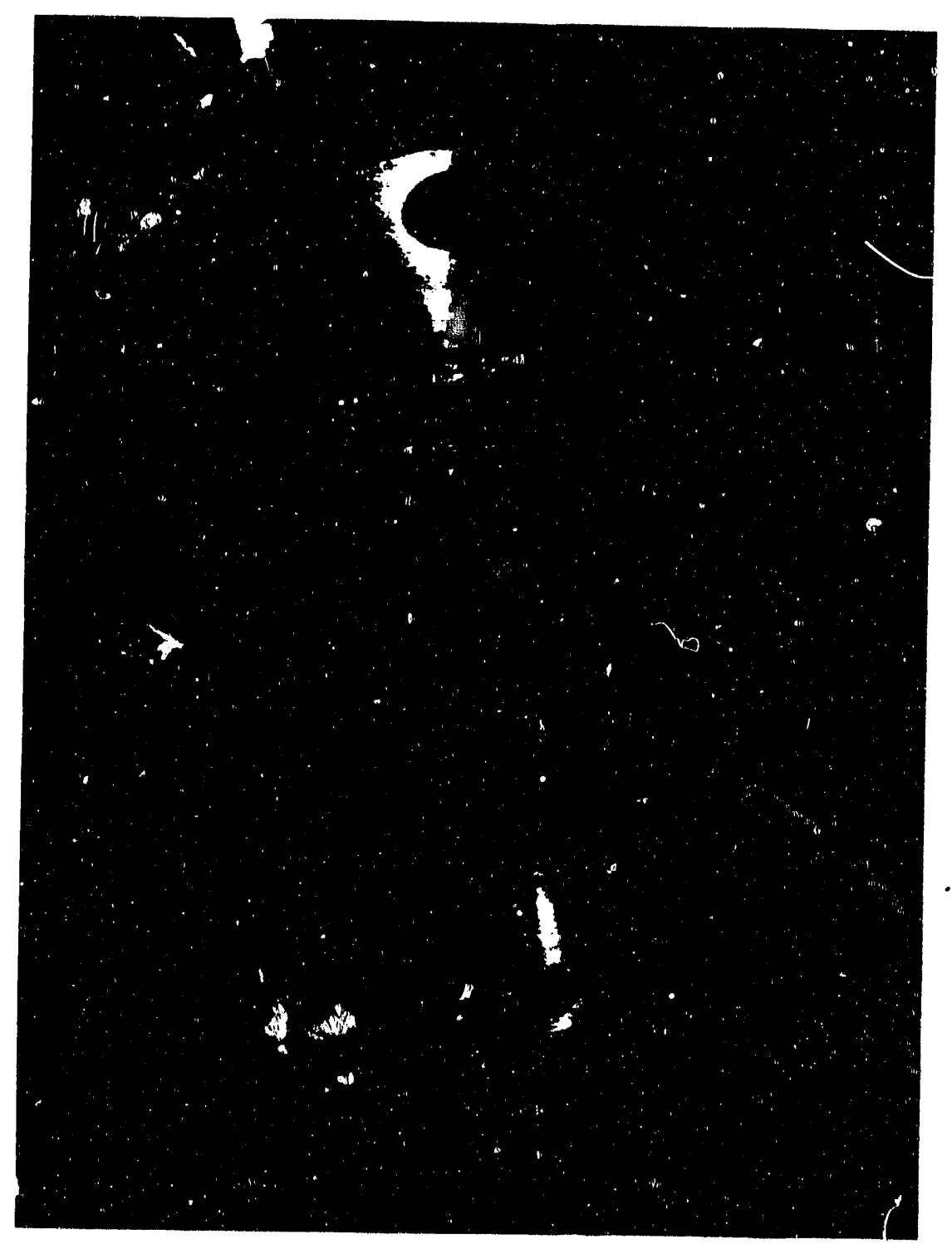

Figure 4. Dye-Penetrant Test from $1988 \mathrm{ES}$ 


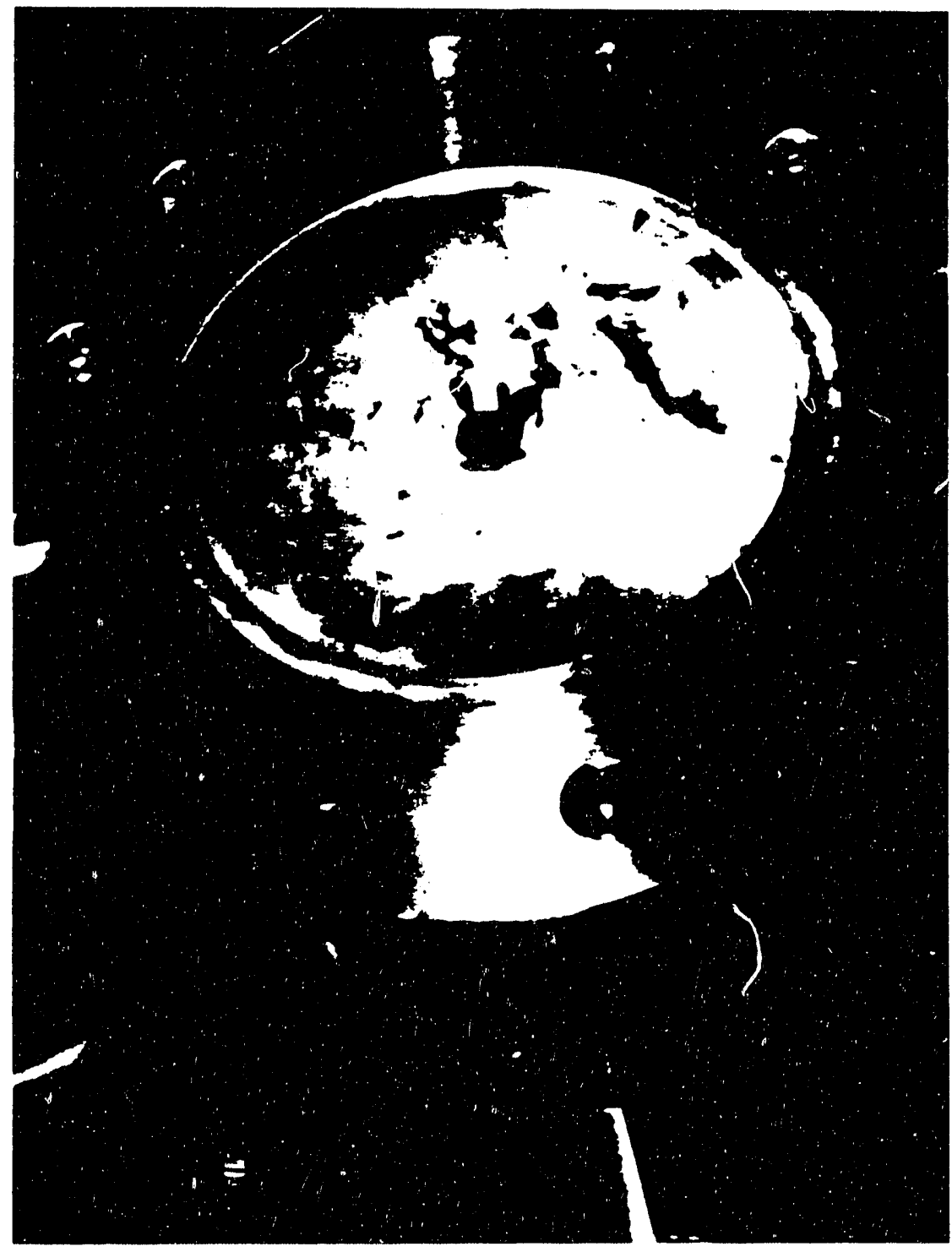

Figure 5. Dye-Penetrant Test from 1989 EB 


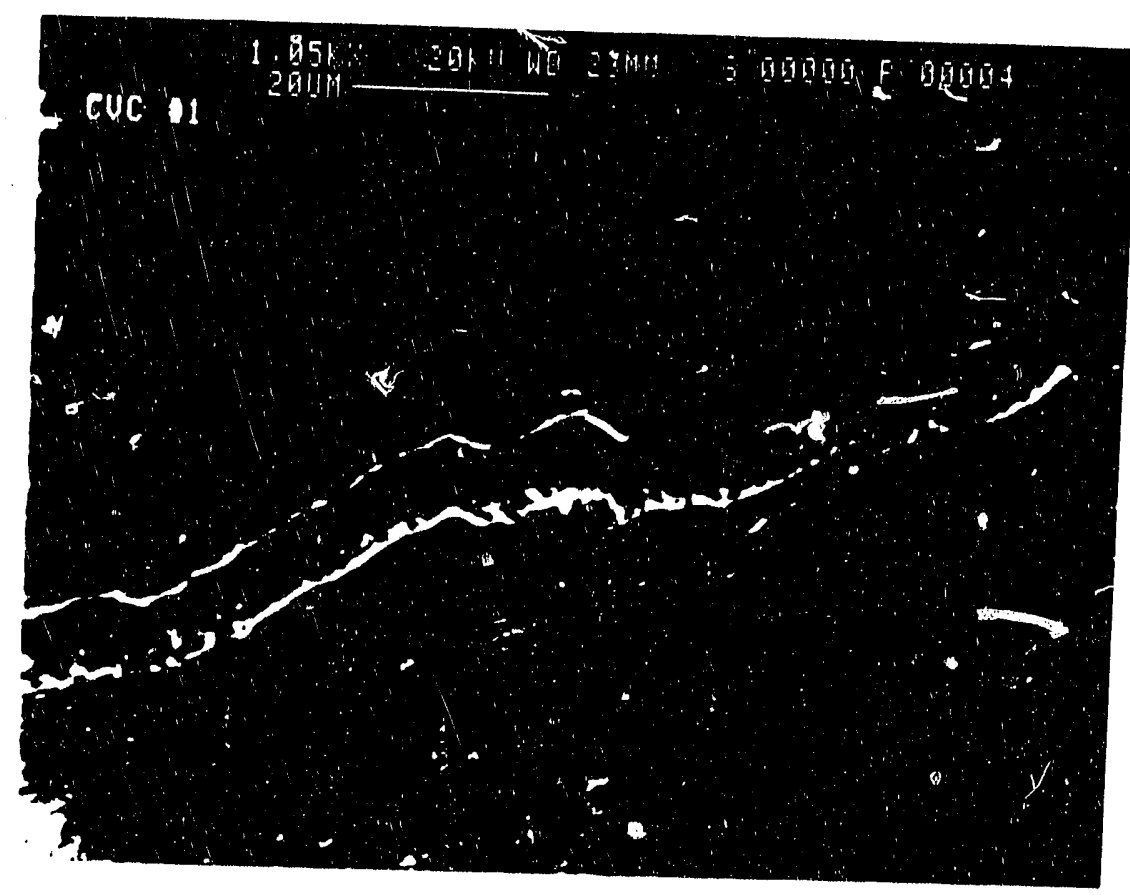

Figure 6. SEM Micrograph of Opened Crack in 1989 EB Welded Stage 


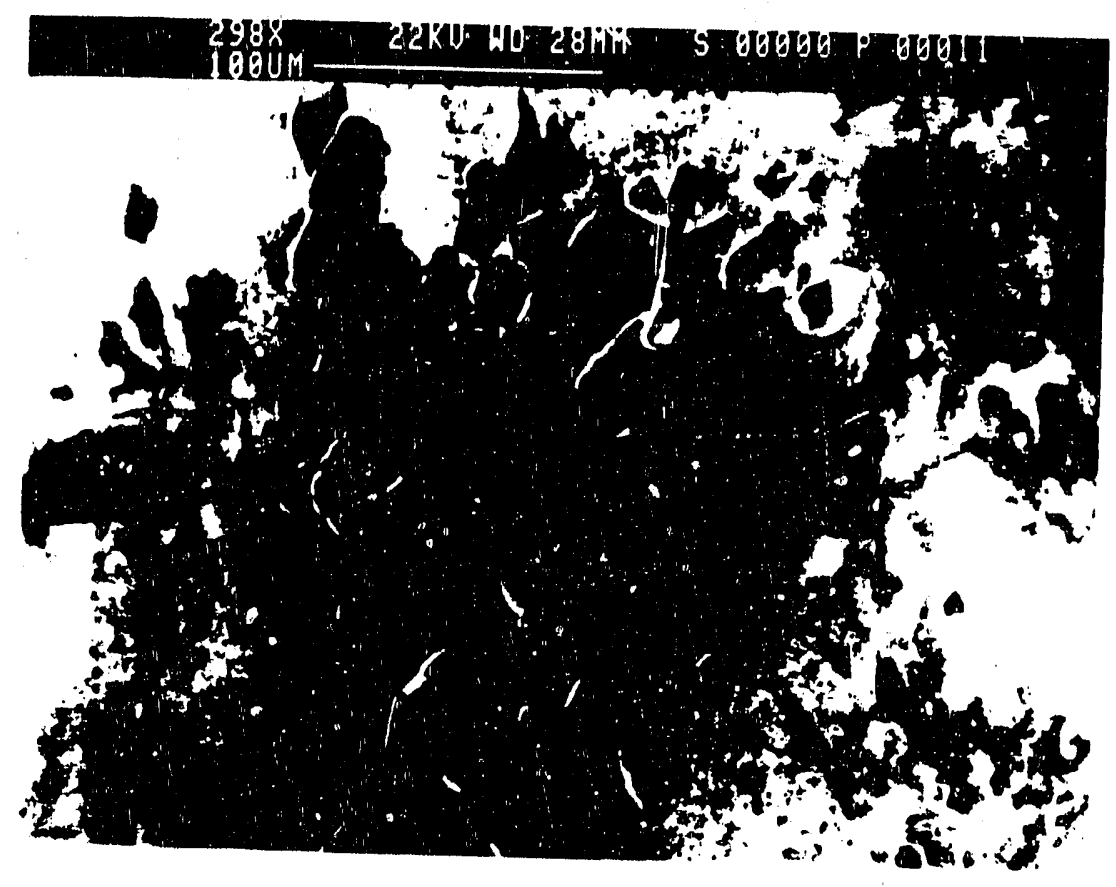

Figure 7. SEM Micrograph Representative of Particles on Mercury Diffusion Pump Stage 


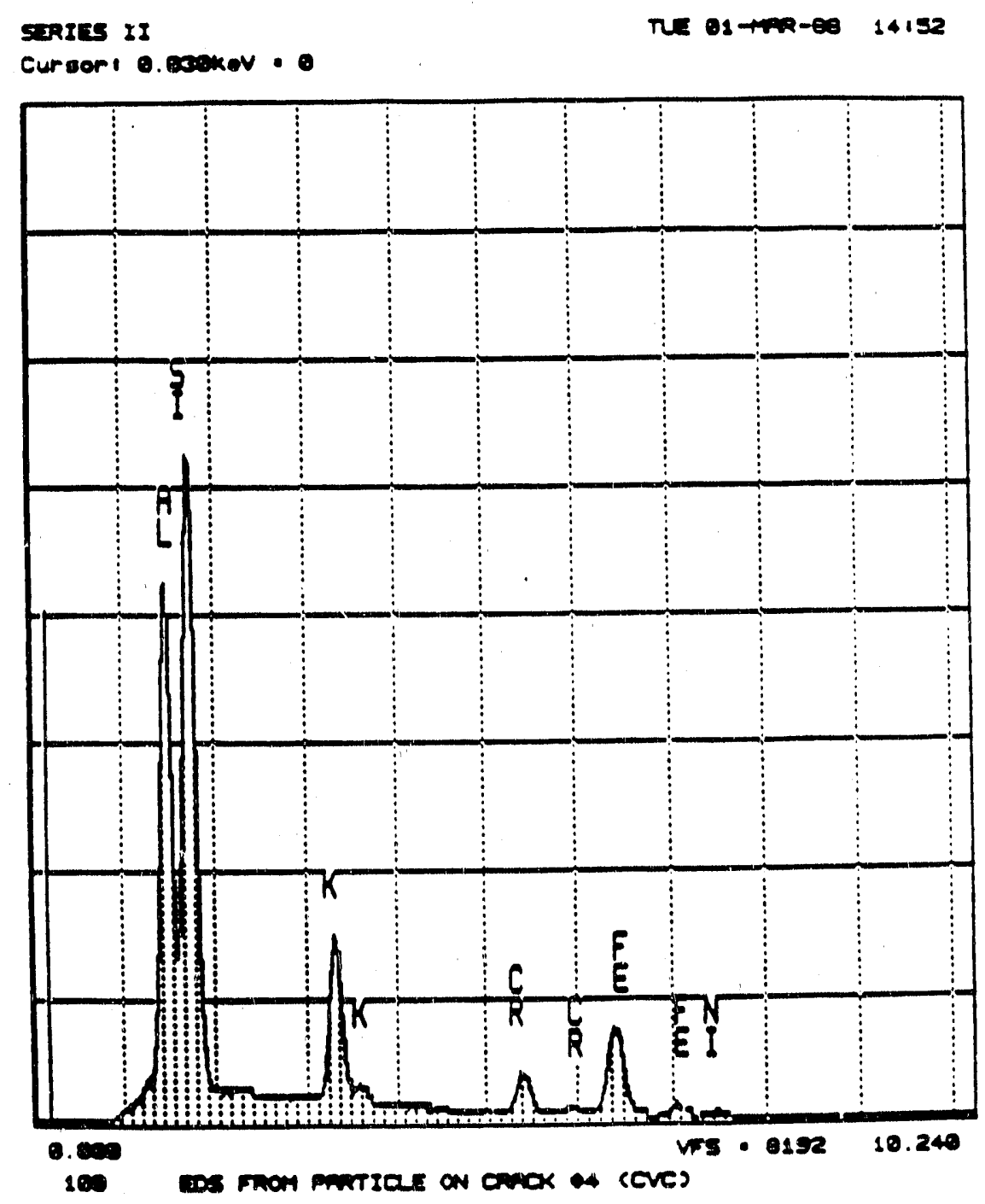

Figure 8. EDS of Particles on Mercury Diffusion Pump Stage 


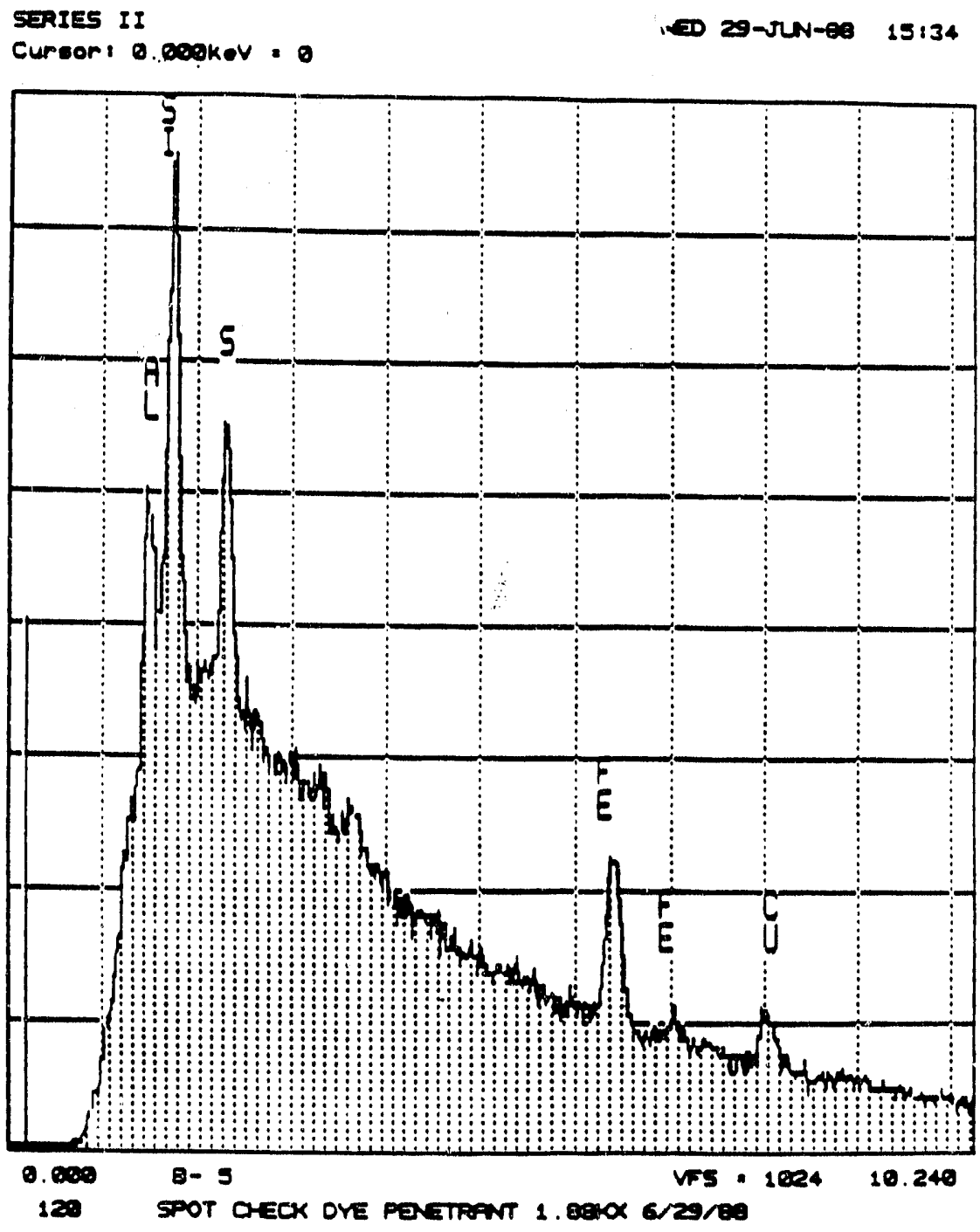

Figure 9. EDS of Dye-Penetrant Check 

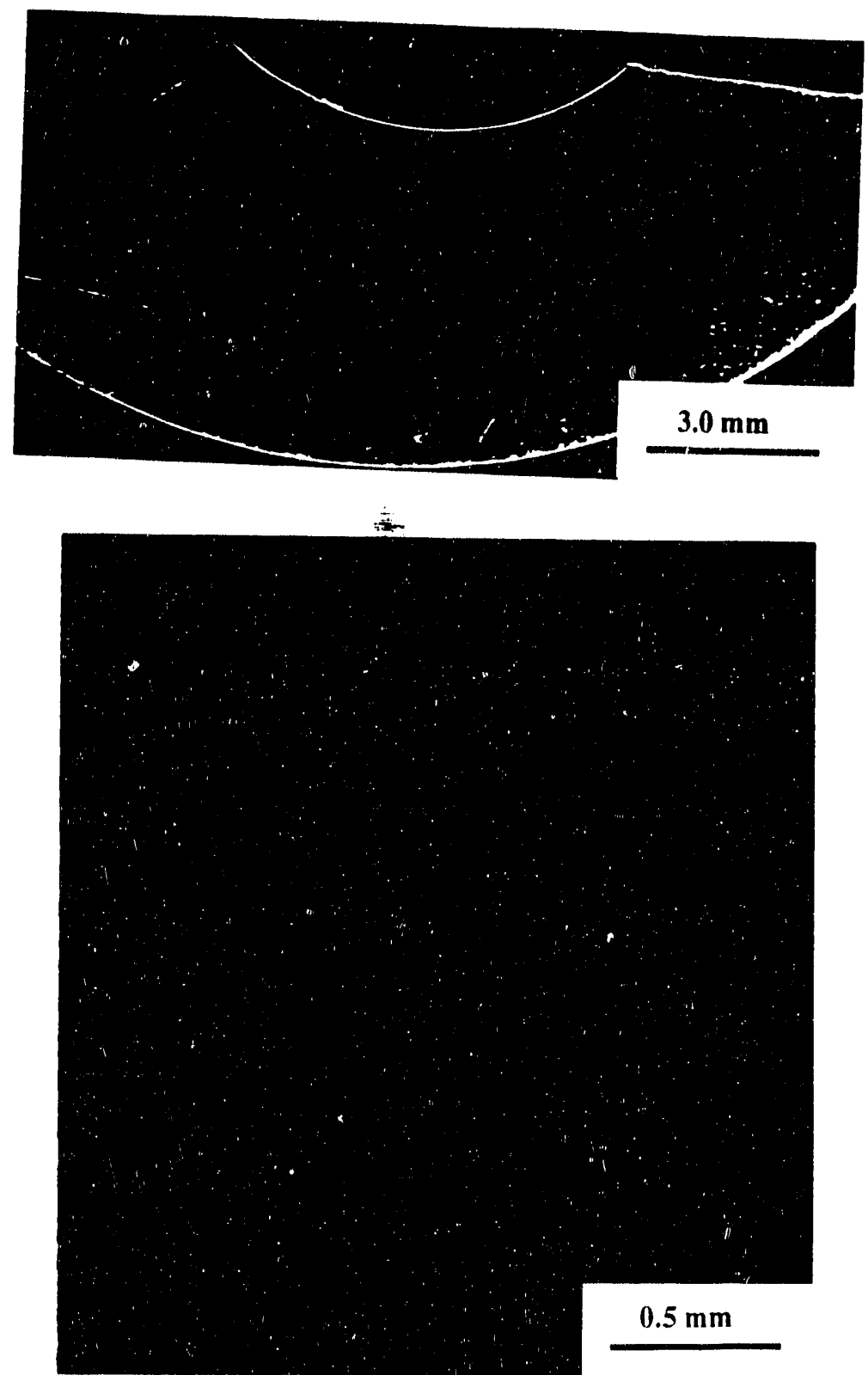

Figure 10. (a) Flange Region of $1988 \mathrm{MP}$

(b) Higher Magnification of Crack in (a) 

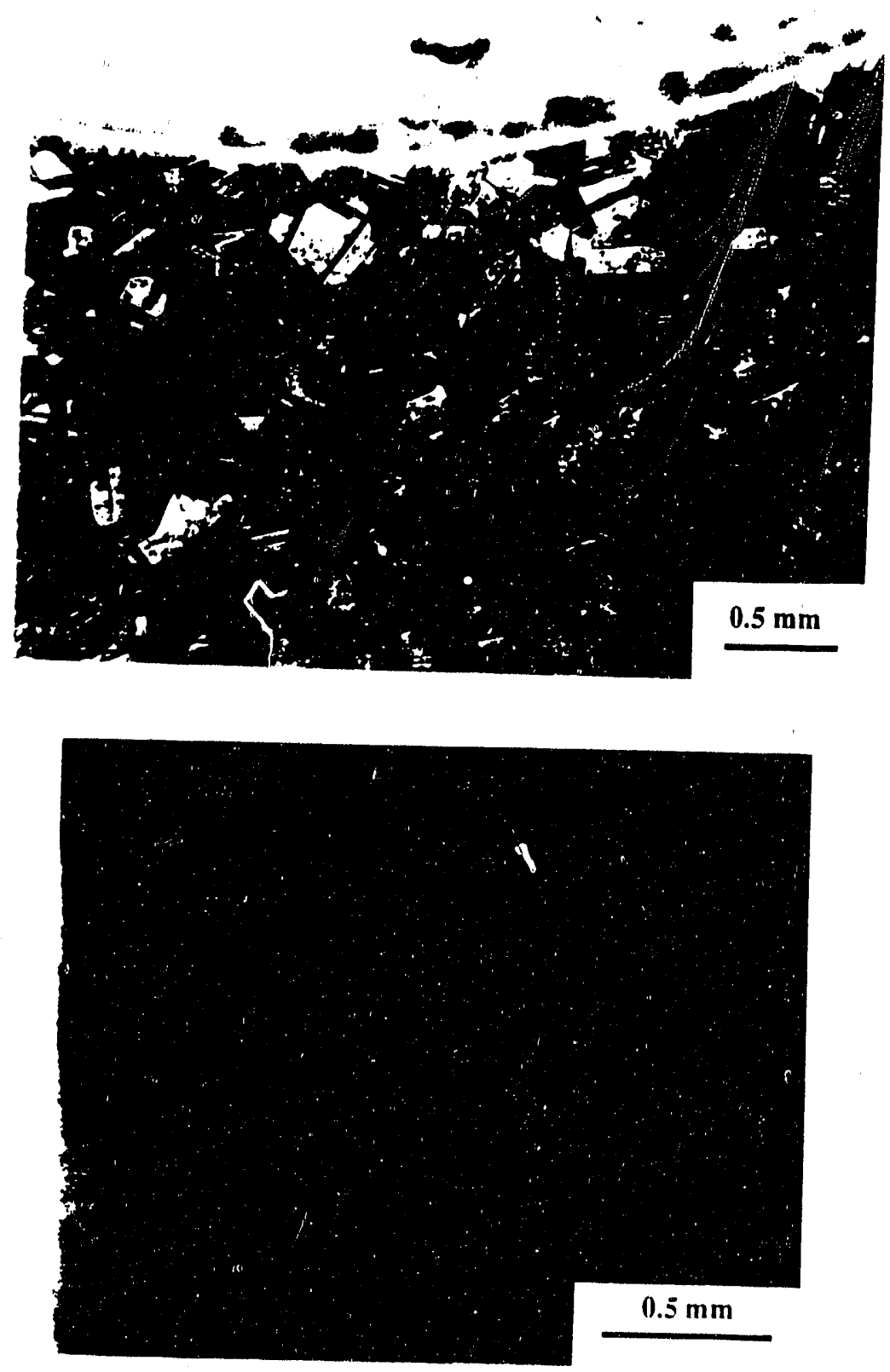

Figure 11. (a) Flange Region of 1988 EB Welded Stage

(b) Higher Magnification of Crack in (a) 


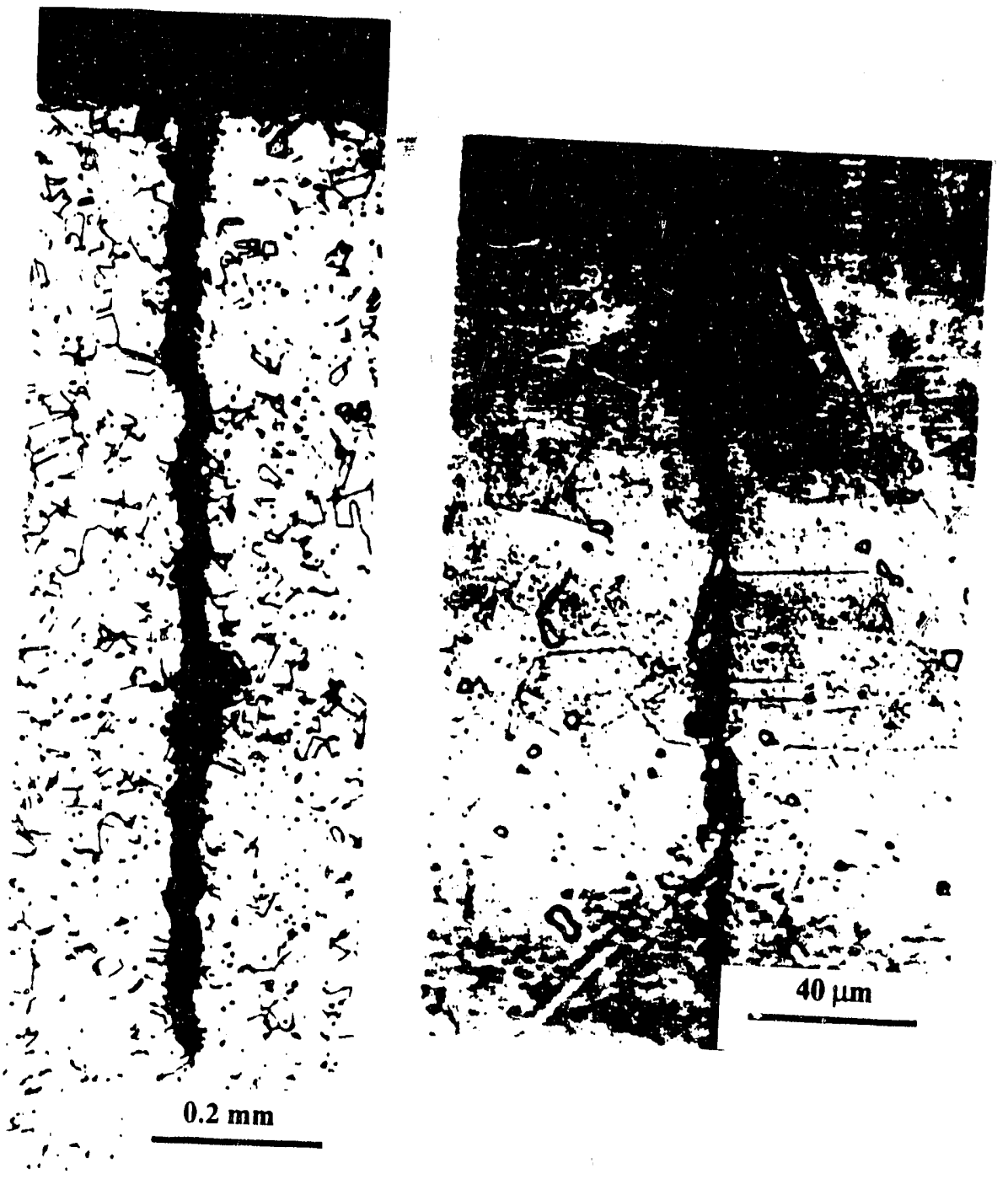

Figure 12. Transverse Section of Crack in 1989 EB Sample (Note the outiined artifacts in the material.) 


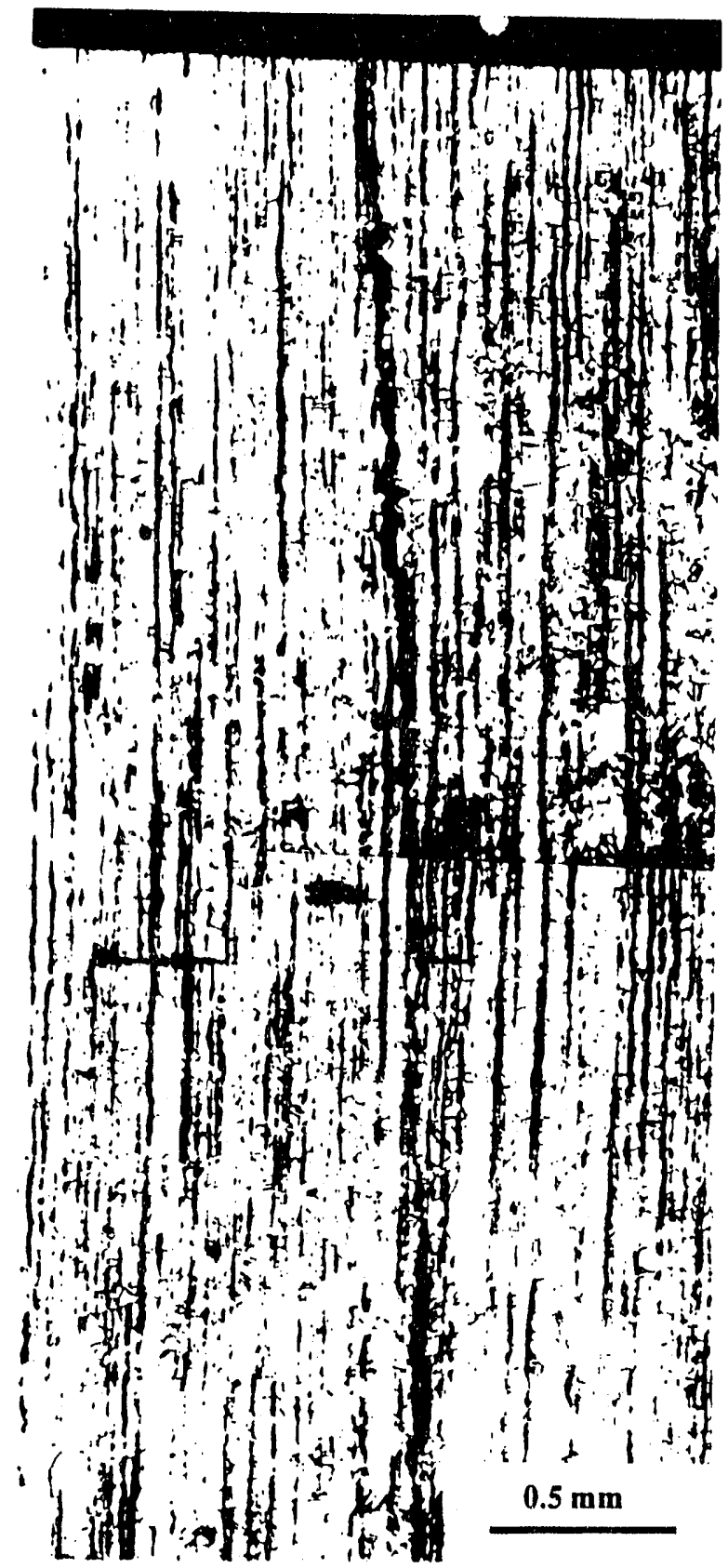

Figure 13. Longitudinal Section of Crack in 1899 EB Stage 


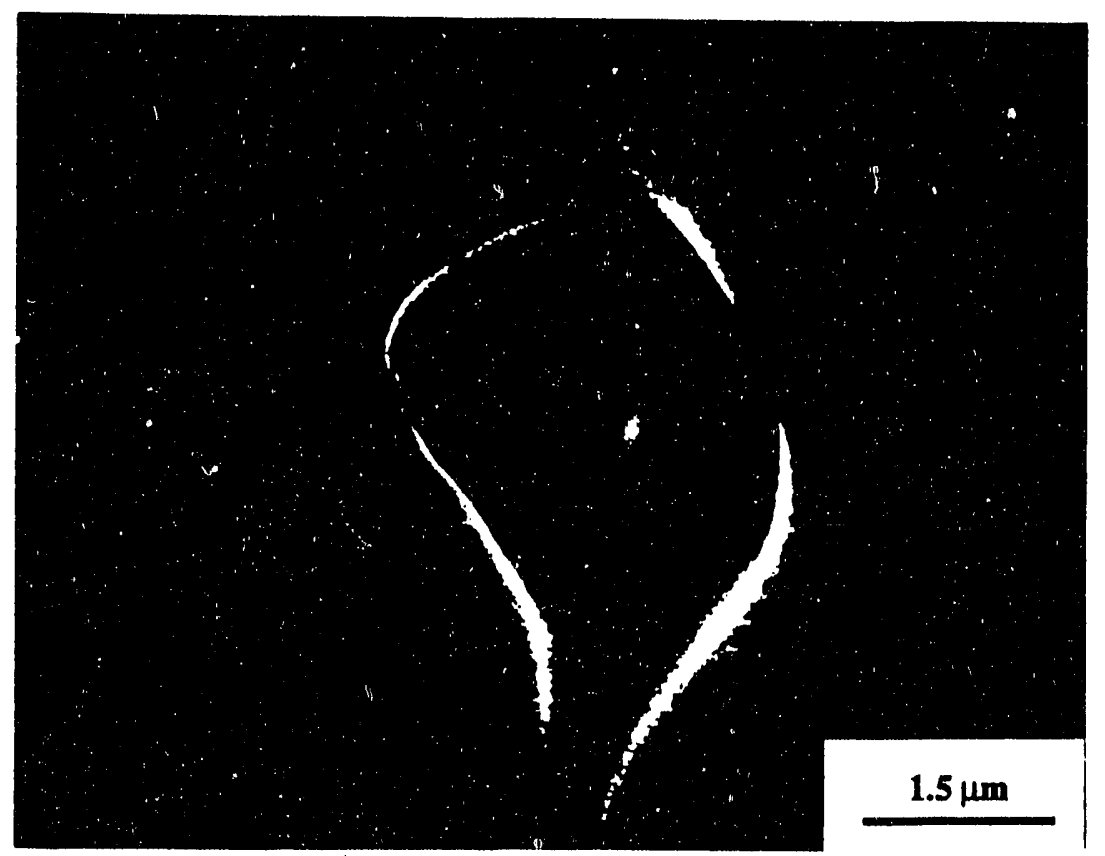

Figure 14. Cr and Mn Rich Particle in Matrix 


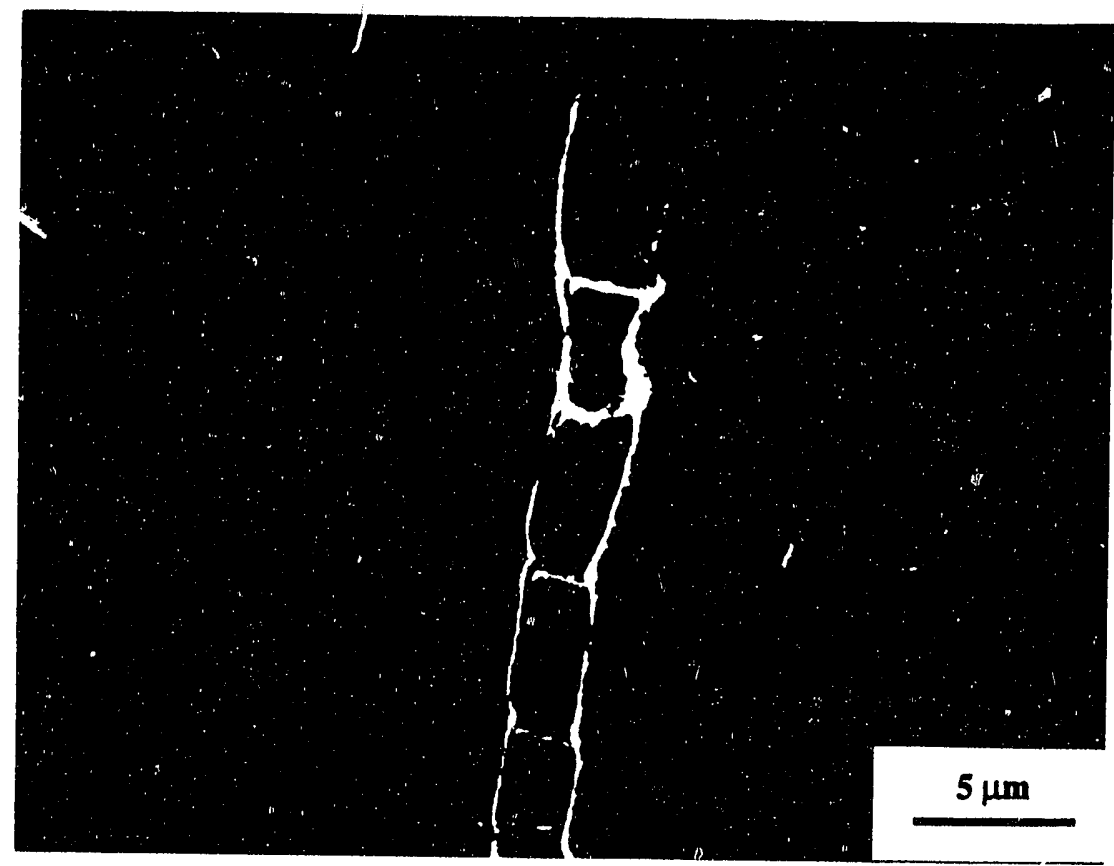

Figure 15. MnS Inclusions in Matrix 


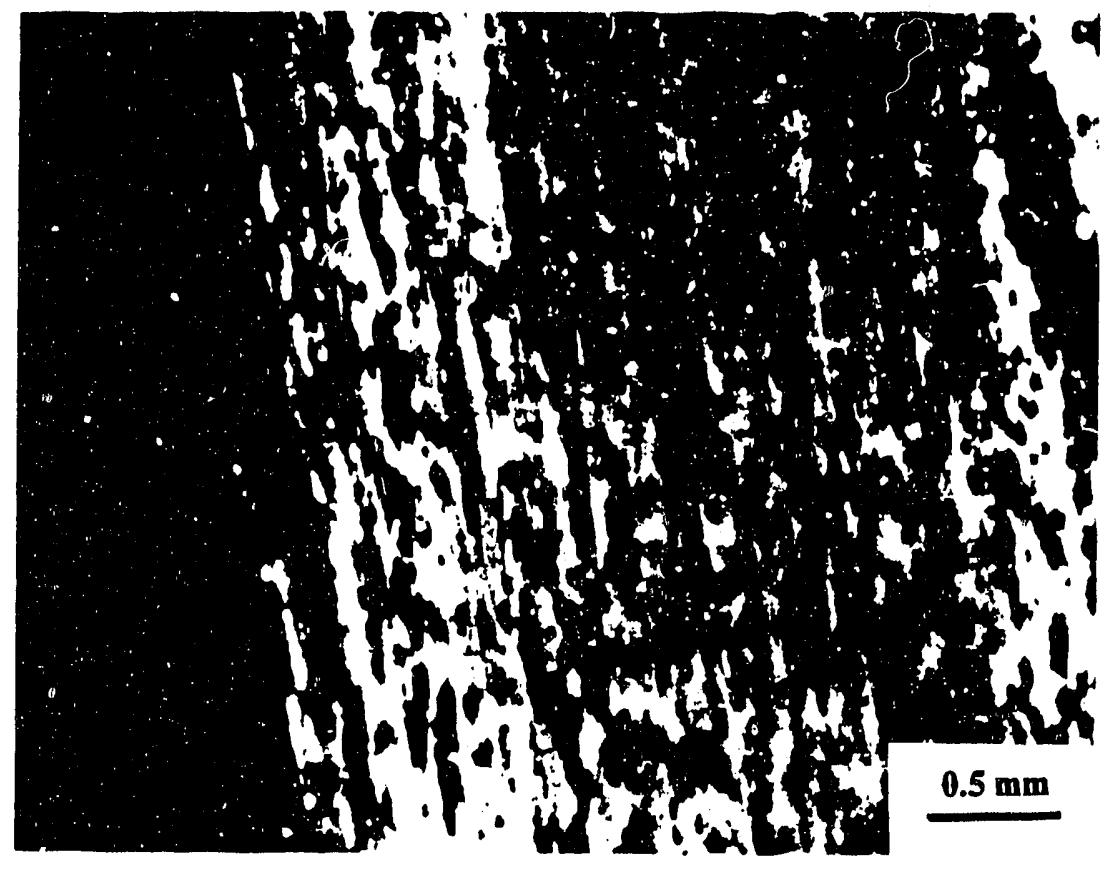

Figure 16. Pits Inside Diffuser Tube from 1988 EB 

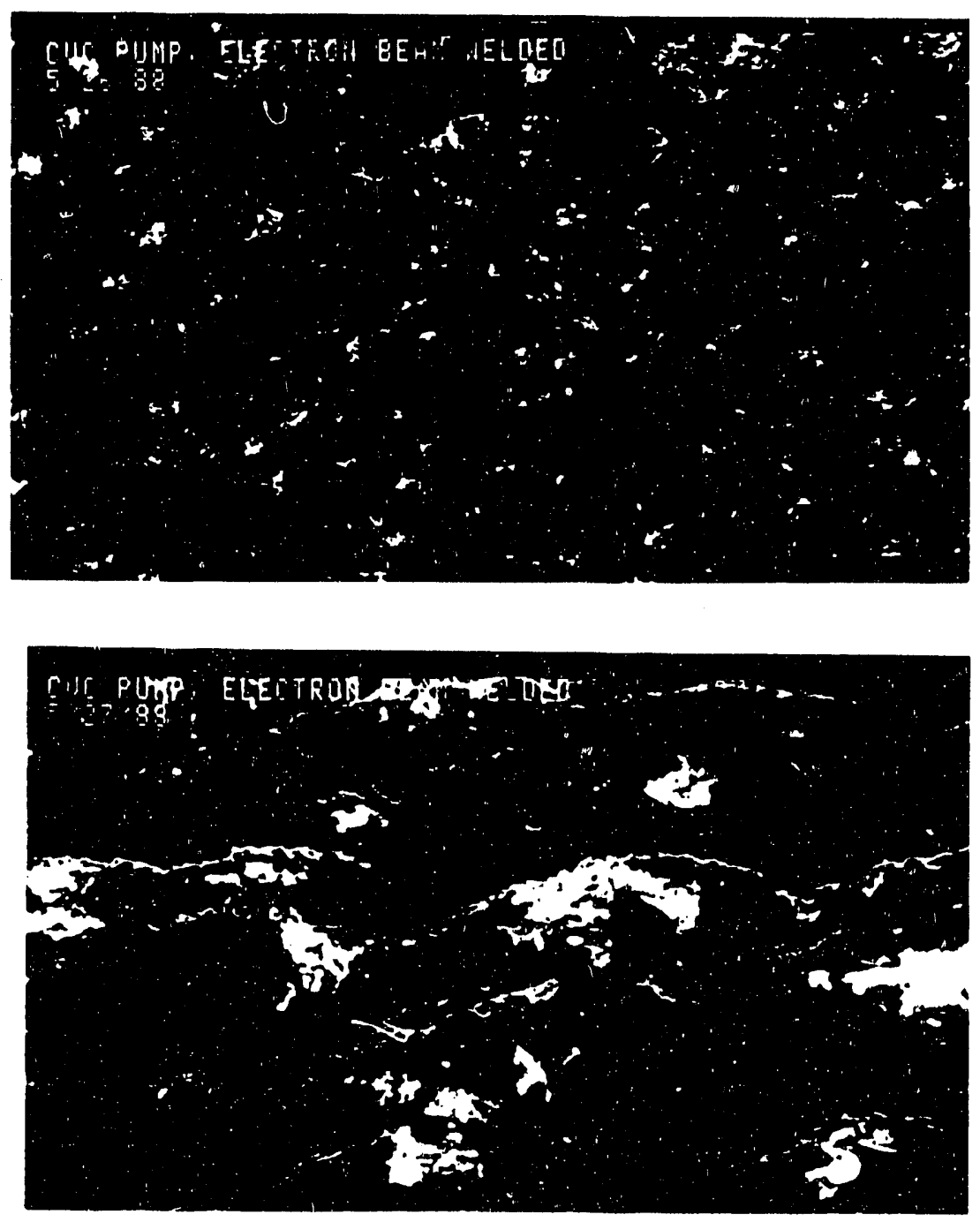

Figure 17. SEM Micrographs of Pits from Inside 1988 EB 

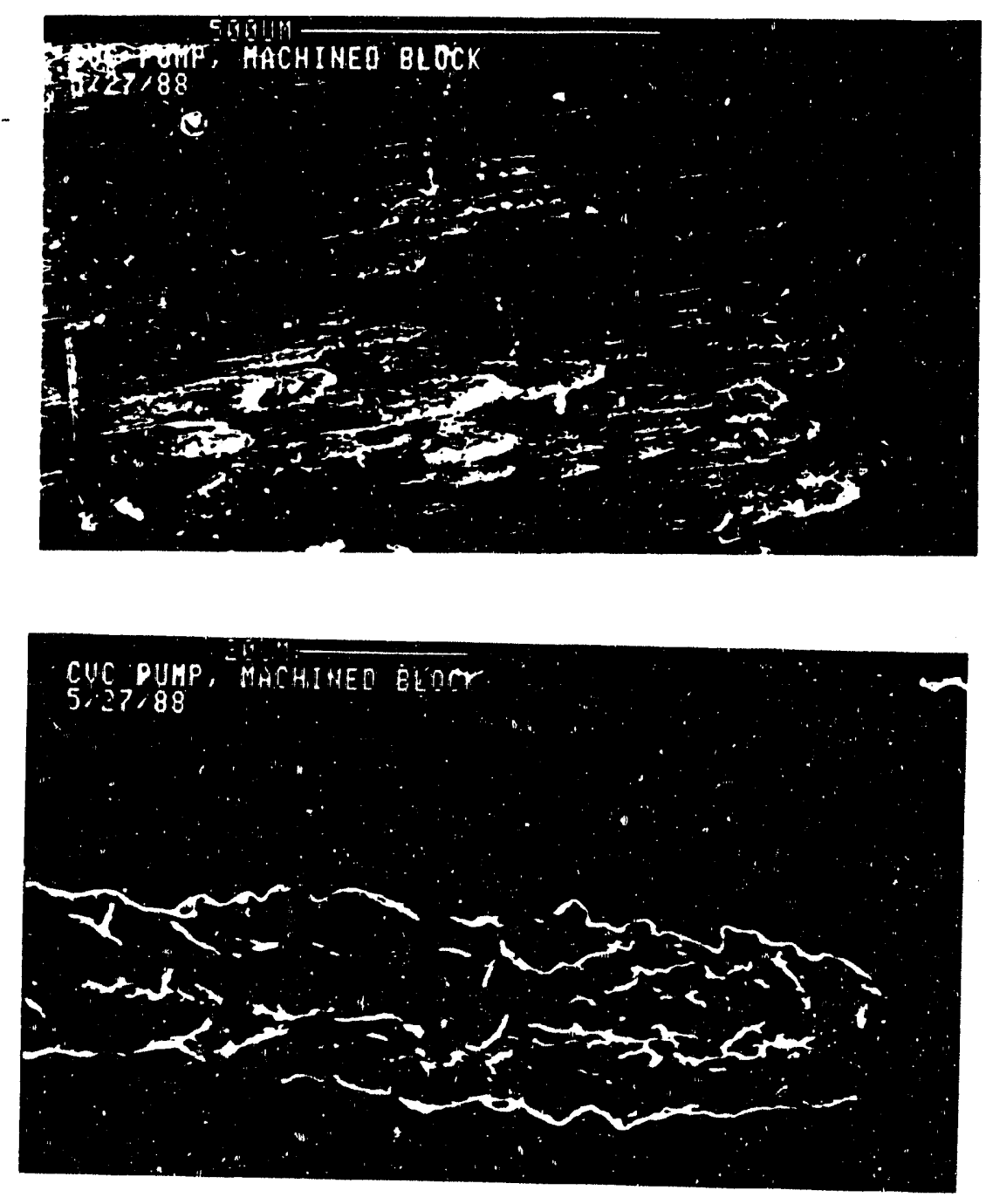

Figure 18. SEM Micrographs of Pits Inside 1988 MP 


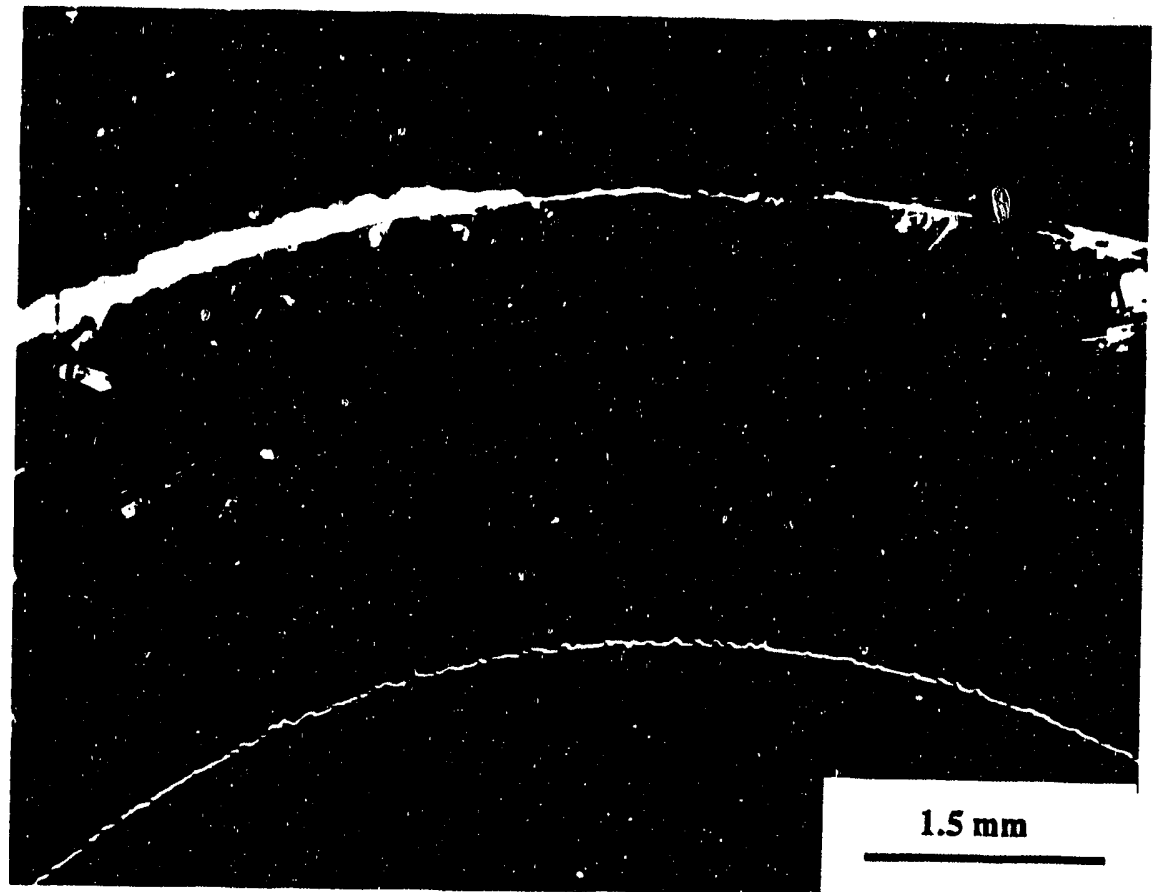

Figure 19. Metallographic Section of Diffuser Tube from 1988 EB 


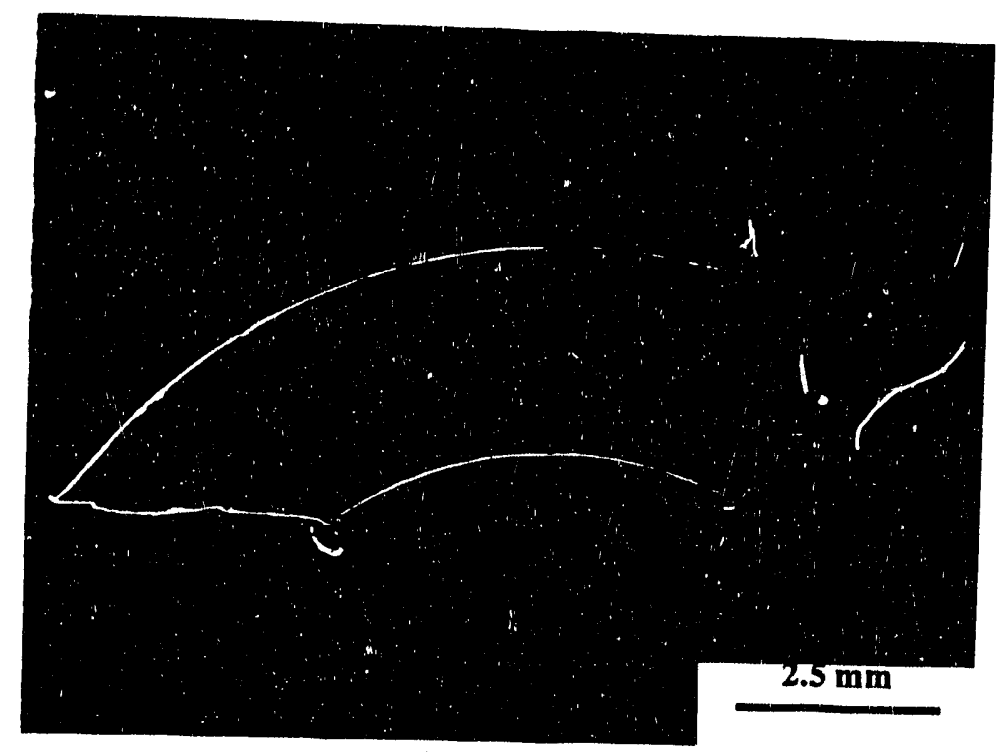

Figure 20. Metallographic Section of Diffuser Tube from 1988 MP 

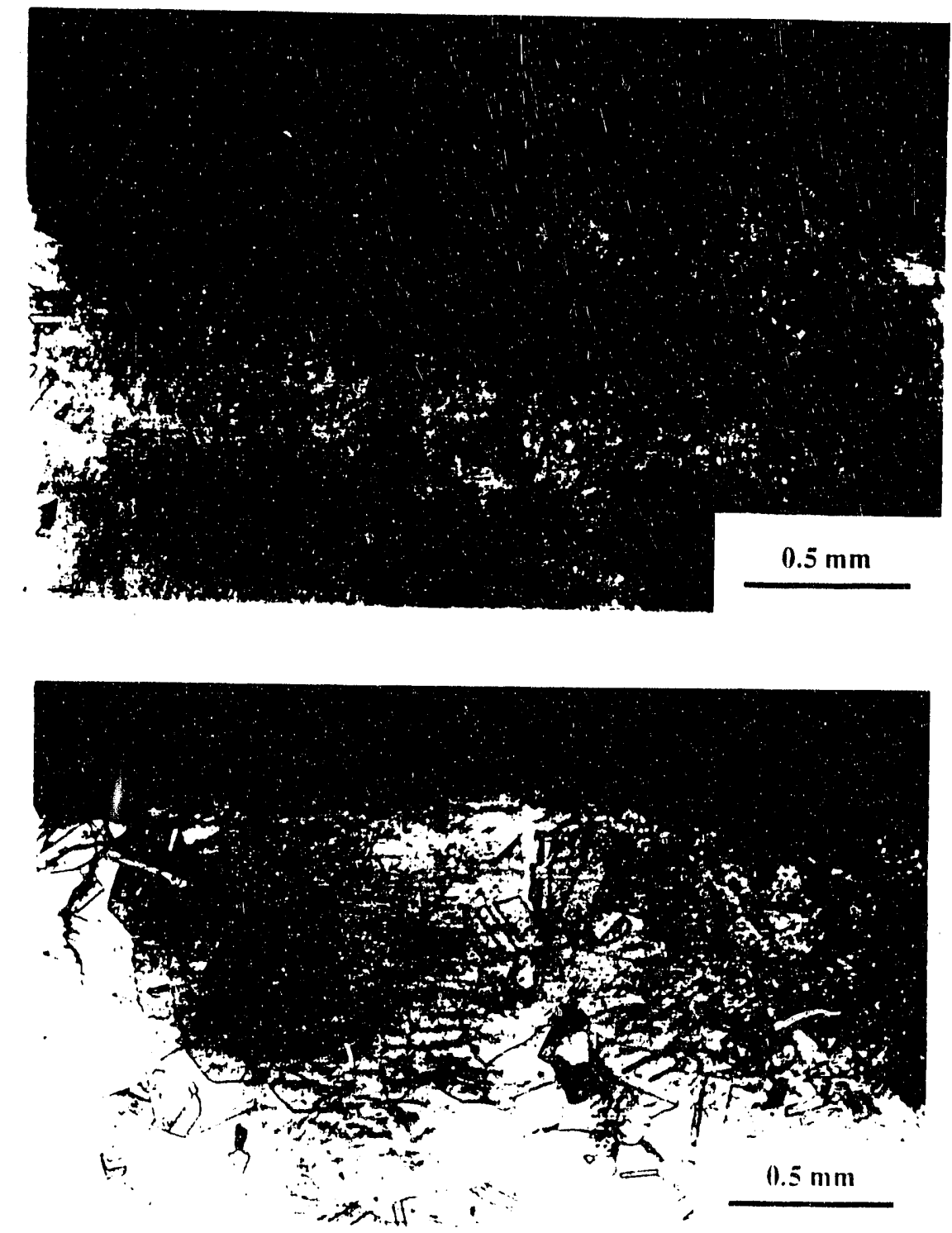

Figure 21. Stress Corrosion Cracks Propagating from Exterior Pits from 1988 EB 


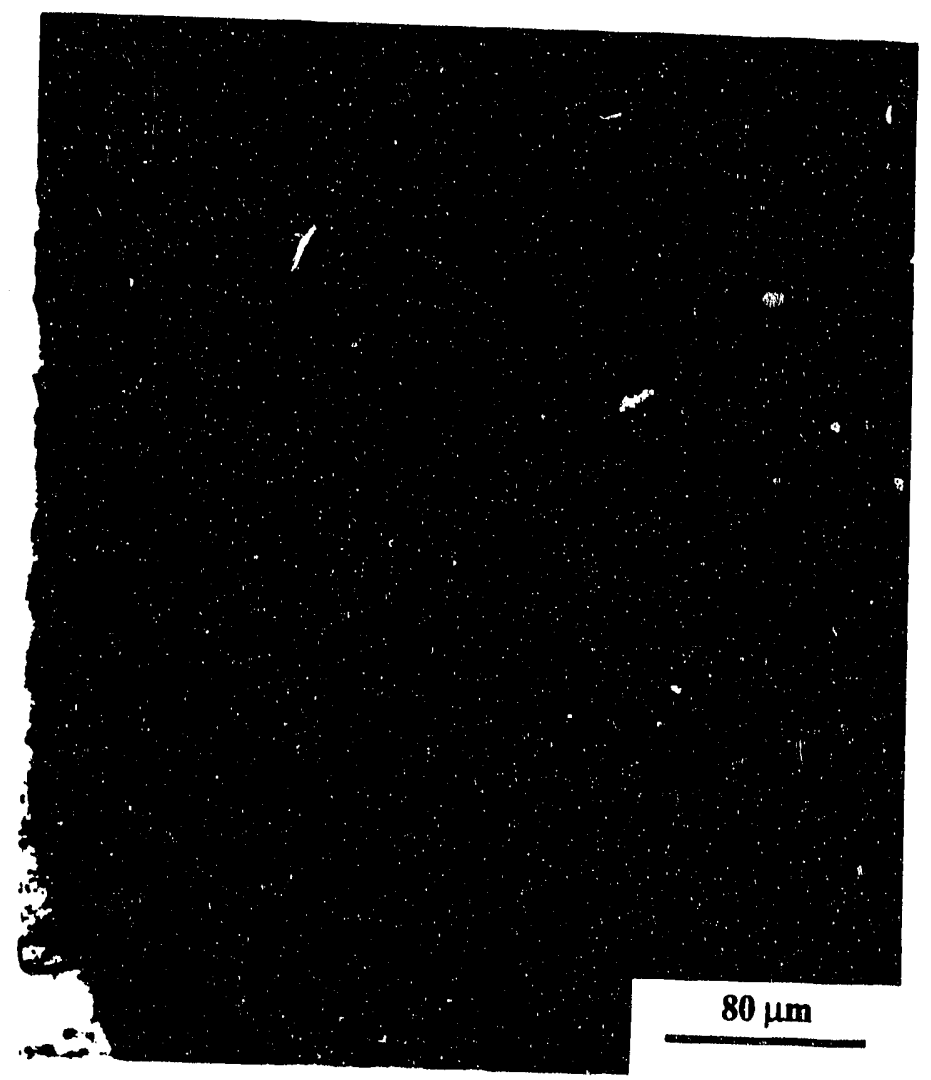

Figure 22. Stress Corrosion Cracks Propagating from Exterior Pits from 1988 MP 

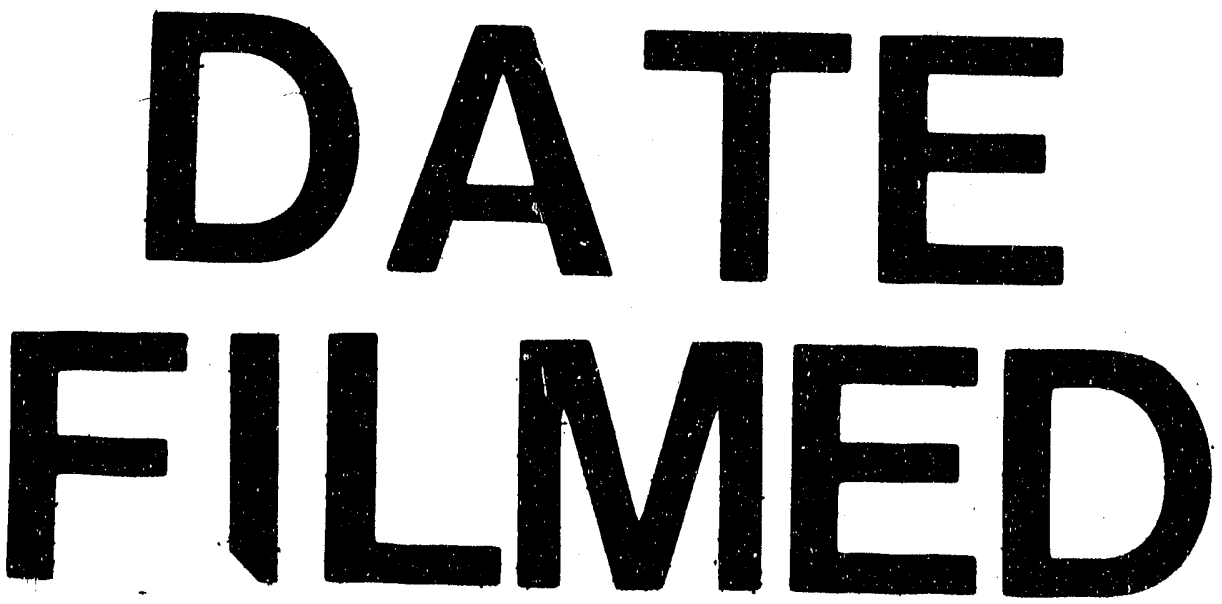

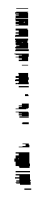

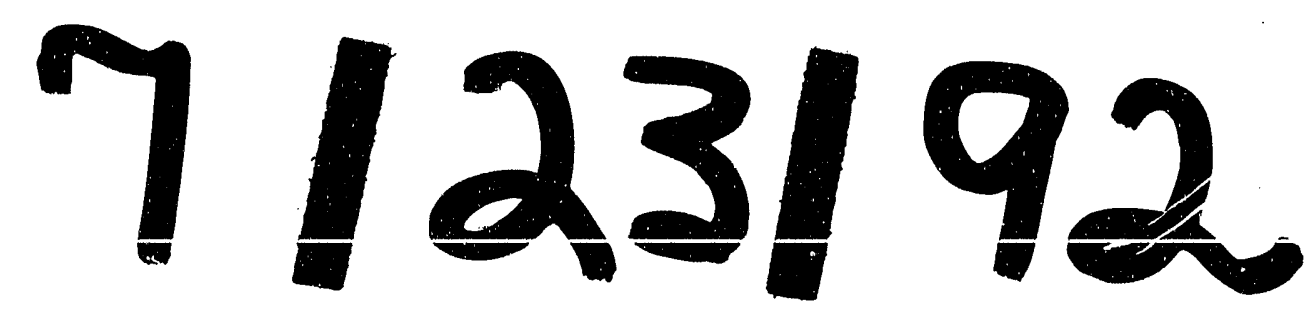


